\title{
Racjonalna struktura usprężynowania wielopoziomowego wagonu specjalnego z wózkami klasycznymi do przewozu ogromnych mas
}

\begin{abstract}
W artykule przedstawiono analizę struktury wagonu wielopoziomowego z wózkami klasycznymi. Analizowano strukturę sprężystq wielopoziomowego uktadu wagonu w poszukiwaniu rozwiqzań, które umożliwiq ruch po nierównościach toru, jakie występuja na przykład podczas wjazdu na prom. Stwierdzono, że wózek klasyczny (z rama ,skrzynkowq”), nie nadaje się do pokonywania ekstremalnych nierówności toru.
\end{abstract}

\section{Wstęp}

Wśród specjalistów kolejnictwa znane są wieloosiowe wagony do przewozu ogromnych ładunków dochodzących $w$ zarządach UIC do 400 ton netto (przy 32 osiach). Jedynie w Ameryce Płn. podobne ładunki dochodzą do 790 ton netto (przy 36 osiach). Są to wagony wolnobieżne o wielopoziomowej strukturze podwozi (rys.1). Największe znane wagony są pięciopoziomowe. Usprężynowane są jedynie wózki, co jest zasadą ogólną dla taboru towarowego. Międzyramowe ślizgi boczne wyższych "poziomów ramowych" takich wagonów są sztywne, z pewnymi luzami. Jakkolwiek każda rama pomiędzy umownymi czołownicami ma skończoną sztywność skrętną, to wagon taki stanowi strukturę sprężystą o dość nieprzewidywalnych właściwościach ze względów bezpieczeństwa na minimalne naciski $\mathrm{w}$ torze o znacznych makro-nierównościach, jakie występują na przykład przy wjeździe w ostry łuk torowy a zwłaszcza przy załadunku na prom.

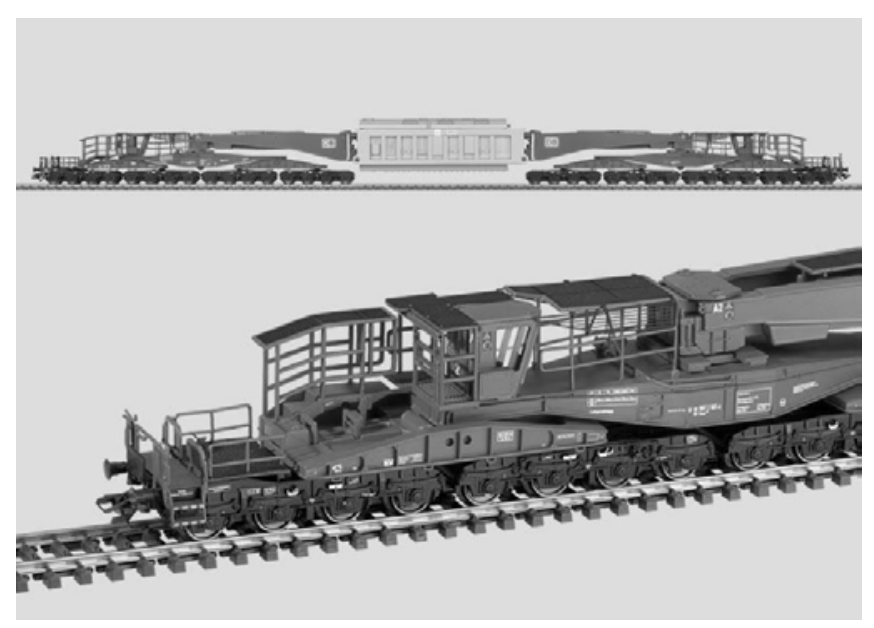

Rys. 1. Wielopoziomowa struktura podwozia wagonu specjalnego

Przewóz ogromnych mas musi być niekiedy dokonywany $w$ trudnych warunkach torowych $\mathrm{i} z$ tego względu zwyczajowa postać sprężystej struktury wagonów z podwoziami wielopoziomowymi powinna zostać zrewidowana dla dostosowania wagonów specjalnych do ekstremalnych warunków torowych. W niniejszym artykule dokonano odpowiedniej teoretycznej analizy usprężynowania wielopoziomowego wagonu specjalnego.

\section{Struktura wagonu}

Miarą bezpieczeństwa wagonu $\mathrm{w}$ torze między innymi moga być współczynniki dopuszczalnej nierównomierności nacisków kół na szyny zarówno przy bocznym przechyleniu wagonu jak i przy przejeździe wagonu w obrębie toru zwichrowanego.

Współczynnik nierównomierności nacisków bocznych $\delta_{\xi}$ kół wagonu specjalnego na szyny wyrażony jest wzorem (1):

$$
\delta_{\xi}=\frac{\left|\sum F_{L}\right|-\left|\sum F_{P}\right|}{\sum F_{L}+\sum F_{P}} ; \quad \sum F_{L}+\sum F_{P}=Q
$$

gdzie: F- nacisk koła na szynę, L - po “'lewej”' stronie pojazdu, $\mathrm{P}$ - po " prawej" stronie,

$\mathrm{Q}$ - nacisk jednego wózka na tor.

Przypadek dotyczy bocznego pochylenia toru $\xi_{\mathrm{t}}$.

Wartość zerowa $\delta_{\xi}$ oznacza, że żadnej nierównomierności nie ma. Jeżeli cały nacisk wagonu przenosi się na tor po jednej stronie, to mamy $100 \%$ zagrożenia.

Wspólczynnik nierównomierności nacisków przekątnych $\delta_{\alpha}$ kół wagonu specjalnego na szyny dla toru zwichrowanego wynosi wg wzoru (2):

$$
\delta_{\alpha}=\frac{\left|\sum F_{1 L}+\sum F_{2 P}\right|-\left|\sum F_{2 L}+\sum F_{1 P}\right|}{\sum F}
$$

gdzie: F- nacisk koła na szynę, 1L - " "przedniej” połowy z ogólnej liczby kół po "lewej" stronie pojazdu, $2 \mathrm{~L}$ - "tylnej" połowy ogólnej liczby osi po "lewej" stronie pojazdu, i podobnie 1P - po "prawej" stronie, $2 \mathrm{P}$ - po "prawej" stronie. 
O ile prosta interpretacja wzoru (1) nie budzi wątpliwości, to wzór (2) należy skomentować. Traktując oddzielnie "przednią" i "tylną" połowę liczby osi wagonu, współczynnik nierównomierności nacisków $\delta_{\alpha}(2)$ odnosi się głównie do najwyższego "poziomu ramowego", który łączy obydwie połówki wagonu.

Tak jest $\mathrm{w}$ istocie. Albowiem zasadą budowy wagonów wielopoziomowych powinna być statyczna wyznaczalność nacisków kól na szyny w obrębie pełnej struktury podwozia.

Zatem poszczególne wózki mogą znajdować się na rozmaitych nierównościach i zwichrowaniach, zaś miarodajna wartość współczynnika nierównomierności nacisków całego wagonu odnosi się do poziomu najwyższego. Konsekwentnie, miarodajnym zwichrowaniem dla całego wagonu (o naciskach statycznie wyznaczalnych) jest to, które mierzy się na podłużnej bazie torowej $\mathrm{B}_{5}$ pod poziomem najwyższym (rys. $2 \mathrm{i}$ $3)$.

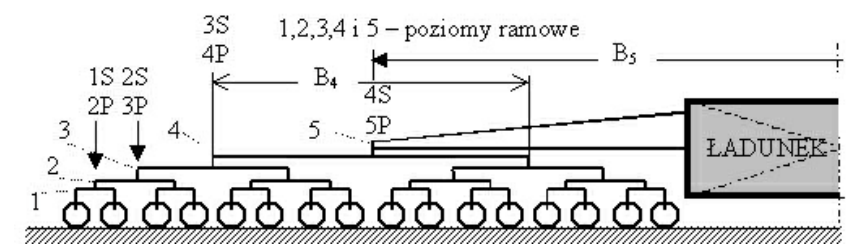

Rys.2. Schemat wagonu wielopoziomowego w torze płaskim

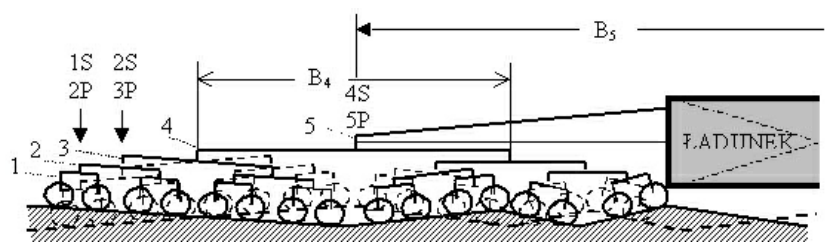

Rys. 3. Ilustracja ruchu wagonu wielopoziomowego po nierównościach toru

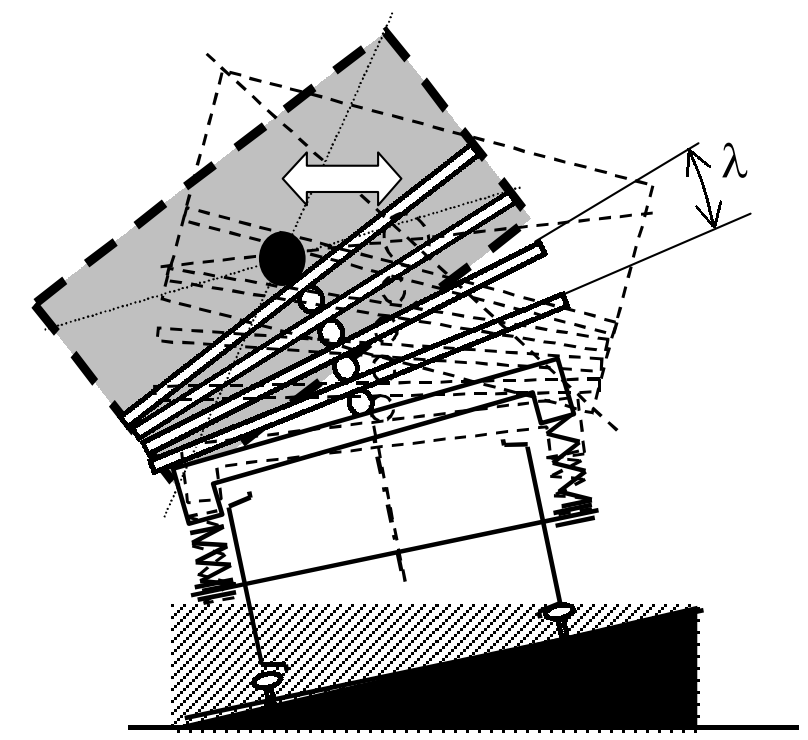

Rys. 4. Ogólnie niestabilne (niejednoznaczne) położenie struktury podwozia wielopoziomowego z kątowymi luzami swobodnymi $\lambda \mathrm{w}$ torze $\mathrm{w}$ zależności od przechyłki kinematycznej, (czyli od prędkości ruchu w torze zakrzywionym)
Jeżeli naciski kół na tor są w obrębie podwozia statycznie wyznaczalne, to na położenie poziomu 5 maja wpływ jedynie te (miarodajne) nierówności toru, które występują na bazie podłużnej $\mathrm{B}_{5}$, co zilustrowano rysunkami 4 i 5.

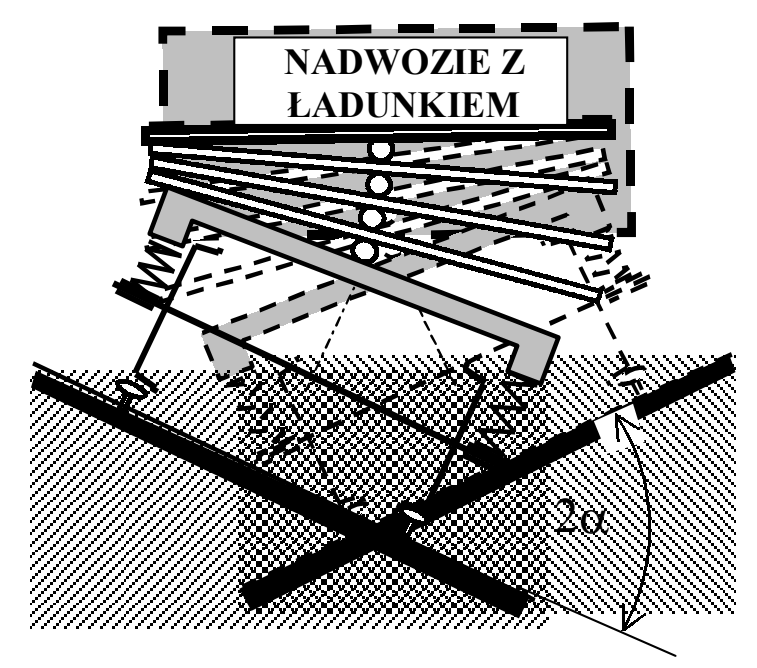

Rys. 5. Ekstremalne zwichrowanie toru $2 \alpha$ pod poziomem ładunkowym wagonu wielopoziomowego z luzami swobodnymi na ślizgach bocznych

Taki stan rzeczy powoduje niemiłe konsekwencje. O ile wagon ładowny może zachowywać dopuszczalną wartość współczynnika $\delta_{\alpha}$, to wagon próżny, (mający tę samą sztywność skrętną mierzoną na bazie $\mathrm{B}_{5}$ ), może się wykoleić przy zbyt niskich naciskach kół odciążonych $\mathrm{w}$ obrębie zwichrowania toru. Powiększanie luzów $\lambda$ na ślizgach bocznych mogłoby poprawić ten stan rzeczy jedynie w odniesieniu do współczynnika $\delta_{\alpha}$, jednak ze względu na fizyczną wymowę współczynnika $\delta_{\xi}$ miałoby to wpływ zgubny zarówno $\mathrm{w}$ torze pochylonym jak i w torze płaskim.

Wagon z luzami swobodnymi na ślizgach bocznych, zaprojektowany dla pokonywania znacznych zwichrowań toru, w torze niezwichrowanym nie zachowuje położeń jednoznacznych. Wymagania techniczne odnośnie do $\delta_{\alpha}$ i $\delta_{\xi}$ są sprzeczne, zaś usunięcie tej sprzeczności wymaga zastosowania ślizgów spreżystych $\mathrm{z}$ odpowiednio dużymi luzami na ogranicznikach dla pokonywania ekstremalnych wichrowatości toru. Wyznaczenie zasad racjonalnej budowy podwozi wielopoziomowych z kątowymi luzami sprężystymi stanowi istotne zagadnienie naukowo - techniczne i należy wziąć pod uwagę pełną strukturę sprężystą wagonu.

Wszystkie poziomy ramowe wagonu wyposażonego $\mathrm{w}$ boczne ślizgi sprężyste, podczas ruchu z przechyłką niezrównoważoną $\mathrm{w}$ torze płaskim (niezwichrowanym), podlegają obciążeniom skrętnym działającym w taki sposób, że moment zewnętrzny $M_{x}$ jest przyłożony na umownej "poprzecznicy", zaś reakcje ślizgów sprężystych są przyłożone na umownych "czołownicach" ram wyższych poziomów ( rys.6 ). 
Zatem w takich warunkach ruchu należy brać pod uwagę pełny bilans sprężystych przemieszczeń skrętnych w strukturze wagonu.

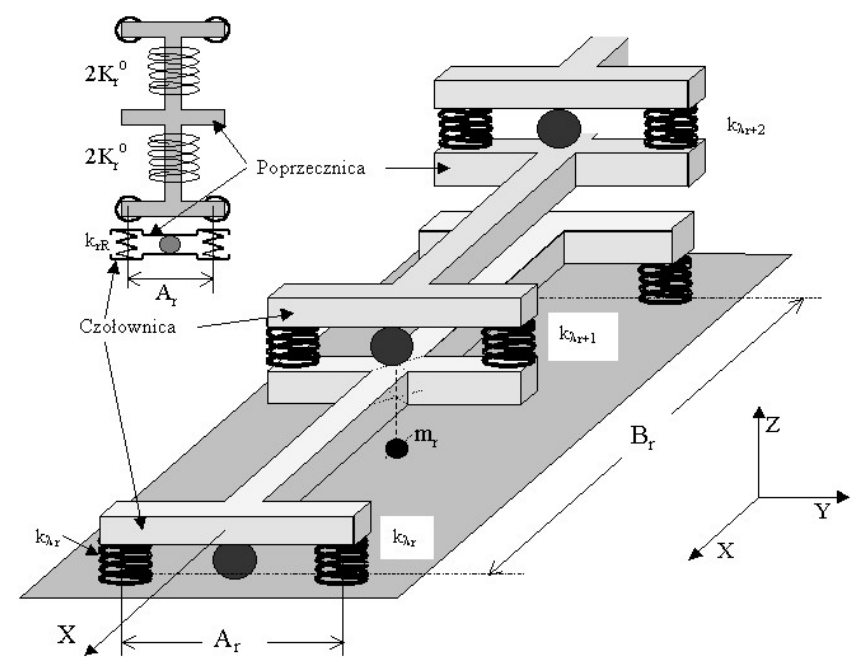

Rys. 6. Model fizyczny współpracujących skrętnie podatnych poziomów ramowych o sztywnościach $\mathrm{K}_{\mathrm{r}}^{\mathrm{o}}$ ze ślizgami sprężystymi o sztywnościach $\mathrm{k}_{\lambda \mathrm{r}}$

Jak pokazano na rysunku $6 \mathrm{w}$ lewym górnym rogu, w płaskim modelu wagonu sztywności skrętne połówek ramy $2 \mathrm{~K}_{\mathrm{r}}^{\mathrm{o}}$ można zastapić sztywnościami pionowymi $k_{r R}$, rozstawionymi na bazie poprzecznej $A_{r}$.

$$
K_{r}^{o}=\frac{1}{2} A_{r}^{2} k_{r R}
$$

Dzięki takiemu zabiegowi cała struktura skrętna wagonu wielopoziomowego ze ślizgami sprężystymi może zostać sprowadzona do zastępczej fizycznej postaci, pokazanej na rysunku 7 .

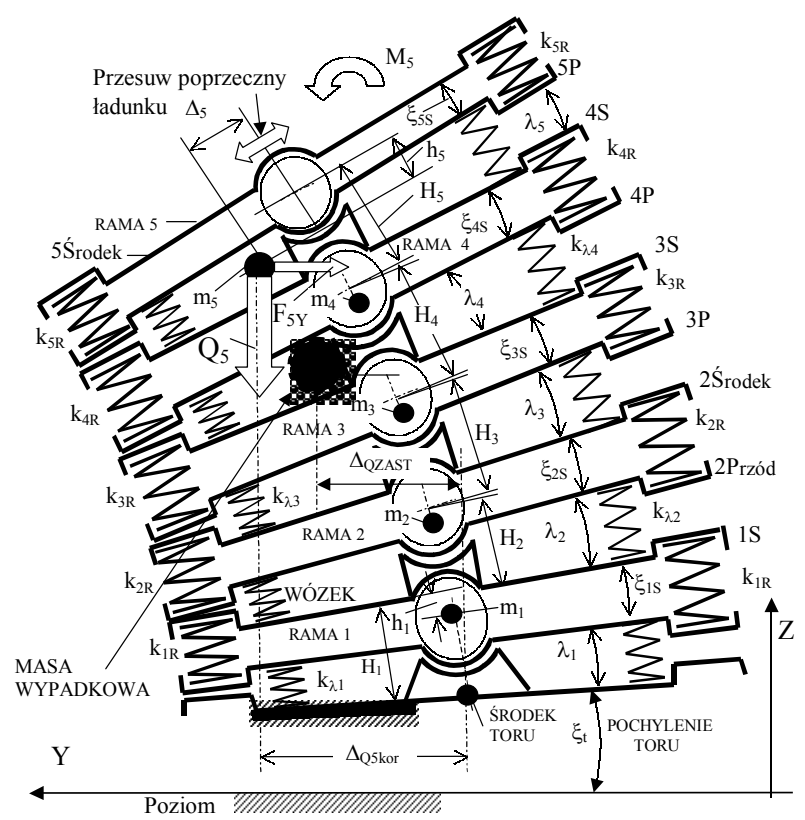

Rys. 7. Zespół skrętnie sprężystych ram z ogólnie sprężystymi luzami na ślizgach bocznych, spoczywający na wózku 1, poruszającym się w tuku toru
Oznaczenia:

$\xi_{r S}-k a t$ skręcenia poprzecznicy ramy " $r$ " w stosunku do jej czołownicy,

$\xi_{I S}$ - kąt pochylenia poprzecznicy wózka 1 w stosunku do pochylonego toru $\xi_{t 1,}$

$k_{1}=k_{\lambda 1}-$ sztywności usprężynowania przypadajace na tożysko osi zestawu,

$\lambda_{r}$ - katowo wyrażone luzy na ślizgach bocznych pod $r$-ta $\operatorname{rama}(r=2,3,4,5)$,

$k_{r R}$ - zastępcze sztywności pionowe odwzorowujace sztywność skrętnq ramy " $r$ ",

$K_{\lambda r}^{o}-$ sztywności pochylania bocznego skrętnie sztywnej ramy, spoczywajacej na sprężystych ślizgach bocznych z katowymi ogranicznikami $\lambda_{r}$.

W celu jednakowego metodycznego potraktowania wszystkich poziomów ramowych zakłada się, że wszystkie te poziomy mają $\mathrm{w}$ narożach podporowych ogólnie pojmowane ślizgi sprężyste $\mathrm{z}$ ogranicznikami bocznych pochyleń traktowanymi kątowo jako $\lambda_{\text {r }}$. Również wózek (czyli 'poziom ramowy pierwszy"), potraktowano podobnie, przy czym usprężynowanie 1-go stopnia $\mathrm{w}$ takim ujęciu należy traktować jako „uogólnione ślizgi sprężyste względem toru” z ogranicznikami bocznych ugięć traktowanych kątowo jako $\lambda_{1}$.

W praktyce każdy wózek ma sztywne ograniczniki ugięć usprężynowania zarówno pod względem przemieszczeń pionowych jak i kątowych bocznych. Inicjujące pochylenie kątowe wagonu, pochodzące od przechyłki toru, należy traktować jako pochylenie narzucone od zewnątrz; według rys. 7 wystepuje początkowo $\lambda_{\mathrm{i}}=\varepsilon_{\mathrm{i}} \xi_{\mathrm{t}}, \xi_{\mathrm{iS}}=\rho_{\mathrm{i}} \xi_{\mathrm{t}}$, gdzie $\varepsilon_{\mathrm{i}}, \rho_{\mathrm{i}}-$ współczynniki konstrukcyjne.

\section{Stateczność strukturalna wagonu}

Stateczność strukturalna wagonu, rozumiana jako jednoznaczność centralnego położenia nadwozia wraz $\mathrm{z}$ ładunkiem, jest zachowana, gdy przyrost energii potencjalnej (dodatni jako forma kwadratowa) $\mathrm{d}\left[\Delta \mathrm{U}_{\mathrm{SPR}}\left(\xi_{\mathrm{t}}\right)\right] / \mathrm{d} \xi_{\mathrm{t}}$ odkształcenia elementów sprezżystych ulegających ugięciom przy bocznym pochylaniu toru wraz $\mathrm{z}$ wagonem, będzie bezwzględnie większy aniżeli (fizycznie zawsze ujemny) przyrost energii potencjalnej położenia w polu grawitacyjnym $\mathrm{d} \mid \Delta \mathrm{U}_{\mathrm{WYS}}\left(\xi_{\mathrm{t}}\right) / / \mathrm{d} \xi_{\mathrm{t}}$ elementów wagonu obarczonych masa podczas pochylania tego wagonu.

Ogólny warunek stateczności strukturalnej:

$$
\begin{aligned}
& \Delta U_{S P R}\left(\xi_{t}\right)>\left|\Delta U_{W Y S}\left(\xi_{t}\right)\right| \quad \text { oraz } \\
& \left.\frac{d\left[\Delta U_{S P R}\left(\xi_{t}\right)\right]}{d \xi_{t}}\right|_{\xi_{t}=0^{+}}>\left.\frac{d\left|\Delta U_{W Y S}\left(\xi_{t}\right)\right|}{d \xi_{t}}\right|_{\xi_{t}=0^{+}}
\end{aligned}
$$

Granicę strukturalnej stateczności układu wyznacza się, przyjmując we wzorach (4) znak równości. Przyrost energii potencjalnej odkształcenia elementów sprężystych $\Delta \mathrm{U}_{\mathrm{SPR}} \mathrm{W}$ wyniku pochylenia wagonu jest 
funkcją kątów skręcenia "połówek" wszystkich sprężystych ram $\xi_{\text {is }}$ i sprężystego pochylenia międzyramowego $\lambda_{\mathrm{i}}$. Dla wózków dwuosiowych wagonu 32- osiowego wynosi on:

$$
\begin{aligned}
\Delta U_{S P R}= & 64\left\{\frac{1}{2^{1}} K_{1}^{o} \cdot \xi_{1 S}^{2}+\frac{1}{2^{2}} K_{2}^{o} \cdot \xi_{2 S}^{2}+\frac{1}{2^{3}} K_{3}^{o} \cdot \xi_{3 S}^{2}+\frac{1}{2^{4}} K_{4}^{o} \cdot \xi_{4 S}^{2}+\frac{1}{2^{5}} K_{5}^{o} \cdot \xi_{S S}^{2}\right\}+ \\
& +32\left\{\frac{1}{2^{1}} K_{\lambda 1}^{o} \cdot \lambda_{1}^{2}+\frac{1}{2^{2}} K_{\lambda 2}^{o} \cdot \lambda_{2}^{2}+\frac{1}{2^{3}} K_{\lambda 3}^{o} \cdot \lambda_{3}^{2}+\frac{1}{2^{4}} K_{\lambda 4}^{o} \cdot \lambda_{4}^{2}+\frac{1}{2^{5}} K_{\lambda S}^{o} \cdot \lambda_{5}^{2}\right\}
\end{aligned}
$$

Albo:

$$
\begin{aligned}
& \Delta U_{S P R}\left(\xi_{t}\right)=\sum_{i=1}^{n} \frac{L_{o W A G}}{2^{i}}\left(2 \cdot K_{i}^{o} \cdot \xi_{i S}^{2}+K_{\lambda i}^{o} \cdot \lambda_{i}^{2}\right), \\
& \operatorname{przy\quad czym}: \quad \lambda_{i}=\varepsilon_{i} \cdot \xi_{t} ; \quad \xi_{i S}=\rho_{i} \cdot \xi_{t}
\end{aligned}
$$

gdzie jako $\mathrm{L}_{\text {oWAG }}$ oznaczono liczbę osi $\mathrm{w}$ wagonie $\mathrm{z}$ wózkami dwuosiowymi,

zaś $\varepsilon_{\mathrm{i}}$ oraz $\rho_{\mathrm{i}}-$ dodatnio określone współczynniki konstrukcyjne.

Zatem pochodna przyrostu energii potencjalnej wynosi:

$$
\frac{d\left[\Delta U_{S P R}\left(\xi_{t}\right)\right]}{d \xi_{t}}=2 \xi_{t} \sum_{i=1}^{n} \frac{L_{o W A G}}{2^{i}}\left[2 \cdot K_{i}^{o} \cdot \rho_{i}^{2}+K_{\lambda i}^{o} \cdot \varepsilon_{i}^{2}\right]
$$

Przyrost energii potencjalnej odkształcenia sprężyn w funkcji kąta pochylenia toru $\xi_{\mathrm{t}}$ jest ściśle liniowo zależny od tego pochylenia, zaś pochodna tego przyrostu jest (oczywiście) stała i zarazem dodatnio określona.

Fizycznie ujemny przyrost energii potencjalnej $\mathrm{w}$ polu grawitacyjnym, wynikający ze zmniejszenia wysokości " "wYs" położenia poszczególnych elementów wagonu, jest funkcją zmiany pionowego położenia elementów wagonu w wyniku pochyleń: toru $\xi_{\mathrm{t}}$, położeń kątowych poszczególnych ram $\xi_{\mathrm{i}}$ oraz luzów międzyramowych $\lambda_{\mathrm{i}}$ zgodnie z rysunkiem 7 :

$$
\begin{aligned}
& \Delta U_{W Y S}=m_{1} \cdot g\left(H_{1}-h_{1}\right)\left(1-\cos \xi_{1}\right)+ \\
& +m_{2} \cdot g\left(H_{1}+H_{2}-h_{2}\right)\left(1-\cos \xi_{1}\right)+ \\
& +m_{2} \cdot g\left(H_{2}-h_{2}\right)\left(1-\cos \xi_{2}\right)+ \\
& +m_{3} \cdot g\left(H_{1}+H_{2}+H_{3}-h_{3}\right)\left(1-\cos \xi_{1}\right)+ \\
& +m_{3} \cdot g\left(H_{2}+H_{3}-h_{3}\right)\left(1-\cos \xi_{2}\right)+ \\
& +m_{3} \cdot g\left(H_{3}-h_{3}\right)\left(1-\cos \xi_{3}\right)+ \\
& +m_{4} \cdot g\left(H_{1}+H_{2}+H_{3}+H_{4}-h_{4}\right)\left(1-\cos \xi_{1}\right)+ \\
& +m_{4} \cdot g\left(H_{2}+H_{3}+H_{4}-h_{4}\right)\left(1-\cos \xi_{2}\right)+ \\
& +m_{4} \cdot g\left(H_{3}+H_{4}-h_{4}\right)\left(1-\cos \xi_{3}\right)+ \\
& +m_{4} \cdot g\left(H_{4}-h_{4}\right)\left(1-\cos \xi_{4}\right)+ \\
& +m_{5} \cdot g\left(H_{1}+H_{2}+H_{3}+H_{4}+H_{5}-h_{5}\right)\left(1-\cos \xi_{1}\right)+ \\
& +m_{5} \cdot g\left(H_{2}+H_{3}+H_{4}+H_{5}-h_{5}\right)\left(1-\cos \xi_{2}\right)+ \\
& +m_{5} \cdot g\left(H_{3}+H_{4}+H_{5}-h_{5}\right)\left(1-\cos \xi_{3}\right)+ \\
& +m_{5} \cdot g\left(H_{4}+H_{5}-h_{5}\right)\left(1-\cos \xi_{4}\right)+ \\
& +m_{5} \cdot g\left(H_{5}-h_{5}\right)\left(1-\cos \xi_{5}\right)+m_{5} \cdot g \cdot \Delta_{5} \cdot \sin \xi_{5}
\end{aligned}
$$

We wzorach (8) zgodnie z rys. 7

$$
\xi_{k}=\xi_{t}+\sum_{j=1}^{j=k}\left(\xi_{j S}+\lambda_{j}\right) ; \quad(j=1,2, . . k, .5)
$$

gdzie: $\xi_{\mathrm{k}}$ - kąt pochylenia ramy „k" wagonu w torze pochylonym wg wzoru (9), $\lambda_{\mathrm{j}}=\varepsilon_{\mathrm{j}} \cdot \xi_{\mathrm{t}}, \quad \xi_{\mathrm{js}}=\rho_{\mathrm{j}} \cdot \xi_{\mathrm{t}} ;$ zaś $\varepsilon_{\mathrm{j}}, \rho_{\mathrm{j}}$ - stałe współczynniki konstrukcyjne określone dodatnio.

W wyniku przekształceń formalnych dochodzi się do bardziej zwartej postaci zapisu:

$$
\begin{aligned}
& \left|\Delta U_{W Y S}\right|=g \sum_{i=1}^{n} m_{i}\left(1-\cos \xi_{i}\right)\left(H_{i}-h_{i}\right)+ \\
& +g \sum_{i=1}^{n-1} m_{i+1}\left(1-\cos \xi_{i}\right)\left(H_{i}+H_{i+1}-h_{i+1}\right)+ \\
& +g \sum_{i=1}^{n-2} m_{i+2}\left(1-\cos \xi_{i}\right)\left(H_{i}+H_{i+1}+H_{i+2}-h_{i+2}\right)+ \\
& +g \sum_{i=1}^{n-3} m_{i+3}\left(1-\cos \xi_{i}\right)\left(H_{i}+H_{i+1}+H_{i+2}+H_{i+3}-h_{i+3}\right)+ \\
& +g \sum_{i=1}^{n-4} m_{i+4}\left(1-\cos \xi_{i}\right)\left(H_{i}+H_{i+1}+H_{i+2}+H_{i+3}+H_{i+4}-h_{i+4}\right)+ \\
& +m_{5} \cdot g \cdot \Delta_{5} \cdot \sin \xi_{5}
\end{aligned}
$$

Ostatecznie po dalszych przekształceniach otrzymuje się:

$\left|\Delta U_{W Y S}\right|=g \sum_{r=0}^{n-1} \sum_{i=1}^{n-r} m_{i+r}\left(1-\cos \xi_{i}\right) \cdot\left(\sum_{i=1}^{i+r} H_{i}-h_{i+r}\right)+m_{5} \cdot g \cdot \Delta_{5} \cdot \sin \xi_{5}$

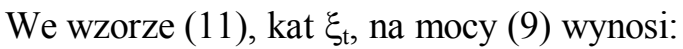

$$
\xi_{i}=\xi_{t}+\xi_{t} \sum_{j=1}^{j=i}\left(\rho_{j}+\varepsilon_{j}\right)=\xi_{t}\left(1+\theta_{i}\right) ; \quad \theta_{i}=\sum_{j=1}^{j=i}\left(\rho_{j}+\varepsilon_{j}\right)
$$

Ze względu na funkcję trygonometryczną "cos" w (10) i (11) dokonano formalnych przekształceń przybliżonych przez zastosowanie rozwinięć $w$ szereg potęgowy. Uwzględniono fakt, że w rzeczywistości ma się do czynienia $\mathrm{z}$ bardzo małymi argumentami cosinusa. Zatem wyrazy (małej wielkości) występujące $\mathrm{w}$ potęgach wyższych od 2 , oraz odpowiednie iloczyny wyższych rzędów niż 2 , odrzucono jako nie mające istotnego znaczenia ilościowego.

Zatem można napisać:

$$
\cos \xi_{i} \approx 1-\frac{\xi_{i}^{2}}{2} ; \quad \sin \xi_{i} \approx \xi_{i}
$$

Konsekwencją powyższego jest dalsze uproszczenie postaci wzoru (11):

$\left|\Delta U_{W Y S}\right|=\frac{g}{2} \sum_{r=0}^{n-1} \sum_{i=1}^{n-r} m_{i+r} \cdot\left(\sum_{i=1}^{i+r} H_{i}-h_{i+r}\right) \cdot \theta_{i}^{2} \xi_{t}^{2}+m_{5} \cdot g \cdot \Delta_{5} \cdot \xi_{t} \cdot \theta_{5}$

a pochodna

$$
\frac{d\left|\Delta U_{W Y S}\right|}{d \xi_{t}} \approx g \sum_{r=0}^{n-1} \sum_{i=1}^{n-r} m_{i+r} \cdot\left(\sum_{i=1}^{i+r} H_{i}-h_{i+r}\right) \cdot \theta_{i}^{2} \cdot \xi_{t}+m_{5} \cdot g \cdot \Delta_{5} \cdot \theta_{5}
$$


Zatem decydującym członem ilościowym jest ostatni wyraz w (14) i (15).

Przyrost energii potencjalnej wysokości $\mathrm{w}$ funkcji kąta pochylenia toru $\xi_{\mathrm{t}}$ jest ogólnie nieliniowo zależny od tego pochylenia, zaś pochodna tego przyrostu jest dodatnio określona i maleje ze wzrostem argumentu. Wyznaczenie wartości kąta $\xi_{\mathrm{t}}$, wg (7) i (15), przy której $\frac{d\left[\Delta U_{S P R}\left(\xi_{t}\right)\right]}{d \xi_{t}}=\frac{d\left|\Delta U_{W Y S}\left(\xi_{t}\right)\right|}{d \xi_{t}}$, określa zakres stateczności strukturalnej pochylonego zespołu sprężystego wg rysunku 7.

Szczegółowe badanie stateczności stanowi zadanie nadające się do analizy cyfrowej.

Warunek (4) należy sprawdzać dla ekstremalnych warunków torowych na podstawie powyższych wzorów. W praktyce jest on bardzo łatwy do spełnienia. Jedynie teoretycznie należy mieć na uwadze, że przy bardzo małych sztywnościach skrętnych ram $\mathrm{K}_{\mathrm{i}}^{\mathrm{o}}$ oraz ślizgów sprężystych $\mathrm{K}_{\lambda \mathrm{i}}^{\mathrm{o}}$, przyrost potencjalnej energii sprężystości może być zbyt mały. W praktyce jednak zagrożenia nie ma, gdyż według wymagań wytrzymałości nośnej, ramy są dostatecznie skrętnie sztywne, zaś $\mathrm{K}_{\lambda_{\mathrm{i}}}^{\mathrm{o}}$ należy dobrać odpowiednio do wymagań przechodzenia wagonu przez zwichrowany odcinek toru.

Sprawdzenie stateczności strukturalnej wagonu należy przeprowadzić przyjmując wartości reprezentatywne (wypadkowe) każdego poziomu ramowego, uwzględniające zarówno sztywność skrętną ram jak i sztywności ślizgów sprężystych dobrane odpowiednio do wymaganej ekstremalnej wichrowatości toru (na przykład w obrębie wjazdu na prom). Wyznaczenie zarówno reprezentatywnych sztywności układu jak i sztywności elementów składowych całości struktury sprężystej wagonu stanowi interesujące, lecz złożone zadanie inżynierskie. Temu zadaniu poświęcono uwagę w niniejszym opracowaniu.

Ogólne podejście metodyczne w tym zadaniu sprowadza się do analizy kolejnego najeżdżania poszczególnych "poziomów ramowych" w obręb toru zwichrowanego. Albowiem wszystkim poziomom racjonalnie zaprojektowanej struktury sprężystej wagonu powinny towarzyszyć takie same wartości współczynnika nierównomierności nacisków przekątnych wg (2) kół na szyny. Najeżdżanie kolejnych poziomów w obręb zwichrowania toru można obserwować w ten sposób, że dany poziom ramowy pozostaje nie pochylony, zaś pochyleniu ulega tor, jak pokazano na rysunkach 5 i 8 . Mieszaną, szeregowo równoległą strukturę obciążania skrętnego zilustrowano rysunkiem 9.

\section{Racjonalna konstrukcja wagonu wielopo- ziomowego}

Pod pojęciem racjonalnej konstrukcji należy rozumieć spełnienie warunku jednakowej dopuszczalnej nierównomierności nacisków kół na szyny pod wszystkimi poziomami ramowymi wg wzoru (2) przy wichrowaniu poszczególnych poziomów ramowych według zasady pokazanej na rys 8 .

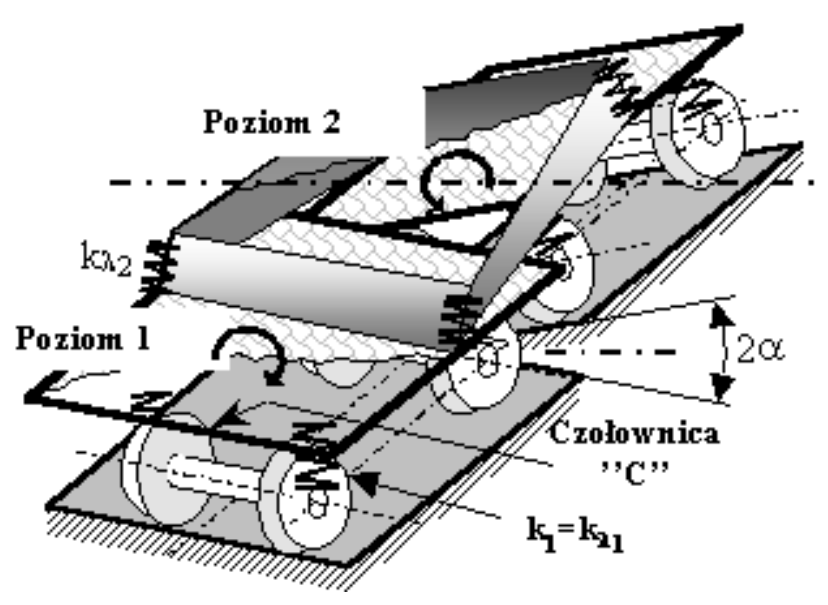

Rys. 8. Modelowe zwichrowanie toru pod poziomem ramowym 2

Zilustrowany przypadek odpowiada fizycznie kolejnemu wjazdowi poszczególnych wózków w obręb ekstremalnej rampy przechyłkowej. Przy analizie wyższych poziomów ramowych nie ważne są wewnętrzne skręcenia struktury sprężystej samych wózków. Układ traktowany jest jako liniowy, co usprawiedliwia przyjęte podejście superpozycyjne.

Konsekwentnie dopuszcza się myśl praktyczną, że poprawnie zaprojektowane (pod względem wytrzymałości i stateczności strukturalnej) ramy wagonu $n$ poziomowego będą miały zbyt duże sztywności na skręcanie $\mathrm{K}_{\mathrm{r}}^{\mathrm{o}}(\mathrm{r}=1,2, \ldots \mathrm{n})$, aby przy sztywnych ślizgach bocznych zapewnić przechodzenie wagonu przez ekstremalną wichrowatość $\mathrm{z}$ należycie bezpiecznymi naciskami kół na szyny wg (2).

Poziom 2 podlega obciążeniu skrętnemu przyłożonemu na jego umownych czołownicach, zaś ramy wózków mają obciążenie skrętne przyłożone na poprzecznicach.

Kompletne usprężynowanie 1 stopnia pojedynczego zestawu ma sztywność pochylania bocznego $\mathrm{K}_{\mathrm{z}}^{\mathrm{o}}$ :

$$
K_{z}^{o}=\frac{1}{2} A_{1}^{2} k_{\lambda 1}
$$

Sztywność bocznego pochylania wózka klasycznego (wg rys. 9) $\mathrm{K}_{\text {wXP }}^{\mathrm{o}}$, przy obciążeniu momentem $\mathrm{M}$ przyłożonym na poprzecznicy 'P" zależy od sztywności wszystkich elementów składowych struktury sprężystej wózka kompletnego:

$$
K_{W X P}^{o}=\frac{2 \cdot K_{z}^{o} \cdot K_{1}^{o}}{K_{z}^{o}+2 K_{1}^{o}}
$$

gdzie $K_{1}^{O}$ - sztywność skrętna ramy wózka mierzona na podłużnej bazie B. 


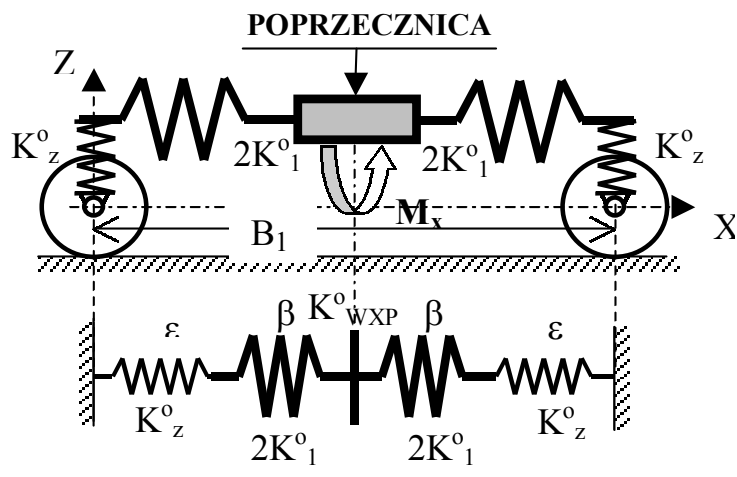

Rys. 9. Schemat obciążenia sprężystej struktury klasycznego wózka „na poprzecznicy” przy wyznaczaniu racjonalnej struktury sprężystej drugiego poziomu ramowego

Jak łatwo sprawdzić,

$$
K_{W X P}^{o}=4 K_{W X Z}^{o}
$$

Sztywność bocznego pochylania wózka (wg rys. 9) $K^{0}{ }_{\text {wxp }}$, przy obciążeniu momentem $M_{x}$ przyłożonym na poprzecznicy " $P$ " jest czterokrotnie większa niż sztywność skrętna wózka kompletnego $\mathrm{K}^{0}{ }_{\text {wxz }}$ przy obciążeniu momentem $\mathbf{M}_{\mathbf{x}}$ przyłożonym pomiędzy osiami usprężynowanych zestawów kól.

Podobnie należy mieć na uwadze fakt, że analizując poziom drugi, jego sztywność (jako układu kompletnego, złożonego $\mathrm{z}$ ramy i ślizgów sprężystych obciążonych szeregowo według rys. 8 przy ich obciążeniu przyłożonym na umownej czołownicy " $\mathrm{C}$ "), wyraża się następująco:

$$
K_{2 X C}^{o}=\frac{K_{\lambda 2}^{o} \cdot K_{2}^{o}}{2\left(K_{\lambda 2}^{o}+2 K_{2}^{o}\right)}=\frac{A_{2}^{2} \cdot k_{\lambda 2} \cdot K_{2}^{o}}{2\left(A_{2}^{2} \cdot k_{\lambda 2}+4 K_{2}^{o}\right)} ; \quad K_{\lambda 2}^{o}=\frac{1}{2} \cdot A_{2}^{2} \cdot k_{\lambda 2}
$$

gdzie: $\mathrm{K}_{\lambda 2}^{\mathrm{o}}$ - kątowa sztywność usprężynowania każdej czołownicy na ślizgach.

Wszystkie międzyramowe ślizgi boczne (na wyższych poziomach) powinny mieć odpowiednio duże luzy sprężyste, dobrane według zasad racjonalności, przy potraktowaniu skrętnych sztywności ram wyższych jako znanych, czyli narzuconych koniecznością konstruktorską (wytrzymałość i stateczność). W świetle powyższego sztywności zastępcze oznaczone jako $\mathrm{K}_{\text {rZAST }}^{\mathrm{o}}$ będą odpowiednio identyfikowane $\mathrm{z}$ oznaczeniem $\mathrm{K}_{2 \mathrm{XC}}^{\mathrm{o}}$ we wzorze (19)

$$
K_{r Z A S T}^{o}=\frac{K_{r}^{o} \cdot k_{\lambda r} \cdot A_{r}^{2}}{2\left(k_{\lambda r} \cdot A_{r}^{2}+4 K_{r}^{o}\right)}=\frac{k_{\lambda r} \cdot A_{r}^{2}}{8\left(\frac{k_{\lambda r} \cdot A_{r}^{2}}{4 K_{r}^{o}}+1\right)}
$$

gdzie: $\mathrm{k}_{\lambda_{\mathrm{r}}}-$ sztywność pionowa ślizgów czoła ramy " $r$ ", $\mathrm{A}_{\mathrm{r}}$ - rozstaw ślizgów, $\mathrm{K}_{\mathrm{r}}^{\mathrm{o}}$ - sztywność skrętna $\mathrm{r}$ tej ramy mierzona na podłużnej bazie podparcia $B_{r}$, $\mathrm{K}_{\text {rZAST }}^{\mathrm{o}}$ - sztywność zespołu ramy "'r" mierzona poprzez jej ślizgi sprężyste przy czym $\mathrm{K}_{\mathrm{rZAST}}^{\mathrm{o}}<<\mathrm{K}_{\mathrm{r}}^{\mathrm{o}}$.

Ekstremalny kąt zwichrowania $\alpha_{\text {rmax }}$ toru pod bazą $\mathrm{B}_{\mathrm{r}}$ ramy o numerze " $\mathrm{r}$ ", wyraża się następująco:

$$
\alpha_{r \max }=\frac{i_{\max } \cdot B_{r}}{2 \cdot 10^{3} \cdot s}
$$

gdzie: s - rozstaw okręgów tocznych w zestawach kół,

$\mathrm{i}_{\max }$ - ekstremalny wznios względny jednego toku szynowego w obrębie rampy przechyłkowej (na przykład promowej 25\%).

Przyjęto poziomą płaszczyznę odniesienia, gdy analizowany poziom ramowy znajdujący się $\mathrm{w}$ stanie zwichrowania oddolnie wymuszonego (wg rys. 8), ma w swym środku pochylenie zerowe.

Dla wyznaczenia wartości parametrów (sztywności i luzów), zapewniających przechodzenie wagonu przez zwichrowanie (np. ekstremalne), należy napisać bilanse bocznych pochyleń elementów struktury sprężystej wagonu kompletnego znajdującego się w torze „czysto” zwichrowanym wedhug rys. 8 , gdzie kąt pochylenia poprzecznicy $\xi_{\mathrm{r}}$ badanego r-tego poziomu ramowego każdorazowo wynosi zero. Dla r-tego poziomu, przy podstawieniu $\xi_{\mathrm{t}}=\alpha_{\max }$, zgodnie z rys. 7 , otrzyma się:

$$
\begin{aligned}
& \alpha_{1 \max }=\xi_{1 S}+\lambda_{1} \\
& \alpha_{2 \max }=\xi_{1 S}+\xi_{2 S}+\lambda_{1}+\lambda_{2} \\
& \alpha_{3 \max }=\xi_{1 S}+\xi_{2 S}+\xi_{3 S}+\lambda_{1}+\lambda_{2}+\lambda_{3} \\
& \alpha_{4 \max }=\xi_{1 S}+\xi_{2 S}+\xi_{3 S}+\xi_{4 S}+\lambda_{1}+\lambda_{2}+\lambda_{3}+\lambda_{4} \\
& \alpha_{5 \max }=\xi_{1 S}+\xi_{2 S}+\xi_{3 S}+\xi_{4 S}+\xi_{5 S}+\lambda_{1}+\lambda_{2}+\lambda_{3}+\lambda_{4}+\lambda_{5}
\end{aligned}
$$

Stąd otrzymuje się wzór w postaci ogólnej dla ramy o numerze "'r":

$$
\frac{i_{\max } \cdot B_{r}}{2 \cdot 10^{3} \cdot s}=\sum_{i=1}^{r}\left(\xi_{i S}+\lambda_{i}\right) ; \quad(r=1,2, \ldots n)
$$

gdzie: $\xi_{\text {is }}$ - kąt skręcenia połowy długości ramy i-tego poziomu ramowego,

$\lambda_{\mathrm{i}}-$ międzyramowy kątowy luz sprężysty pod ramą o numerze 'i'".

Są to wielkości nieznane, które należy wyznaczyć. Analizując wzór (22) widać, że wyznaczanie tych wielkości należy rozpocząć od poziomu pierwszego. Wyznaczone wielkości wynikają $\mathrm{z}$ warunku przechodzenia przez założoną wichrowatość toru i zarazem określają stateczność strukturalną wagonu w każdych warunkach eksploatacyjnych (na przykład przy postoju wagonu pod semaforem w torze pochylonym). 
Warunki wewnętrznej równowagi w układzie sprężystym są spełnione, gdy skręceniu o kąt $\xi_{\text {rs }}$ podlega każda połowa długości r-tej ramy obciążonej momentem $\mathrm{M}_{\mathrm{rC}}$ przyłożonym (zarówno pośrednio jak i bezpośrednio) na umownych czołownicach według rysunków 8 i 9 . W przypadku bezpośredniego przyłożenia momentu $\mathrm{M}_{\mathrm{rC}}$ do czołownic ramy o znanej sztywności skrętnej $\mathrm{K}_{\mathrm{r}}^{\mathrm{o}}$, otrzymanoby kąt skręcenia $\xi_{\text {rs }}$ jej połowy długości:

$$
\xi_{r S}=\frac{M_{r C}}{2 K_{r}^{o}}
$$

$\mathrm{Z}$ drugiej strony graniczny moment $\mathrm{M}_{\mathrm{rC}}$ (przy wyczerpaniu luzu kątowego $\lambda_{\mathrm{r}}$ ) jest przenoszony na ramę szeregowo poprzez każdą parę sprężyn ślizgu bocznego o sztywności $\mathrm{k}_{\lambda_{\mathrm{r}}}$, rozstawionych na szerokości $\mathrm{A}_{\mathrm{r}}$ :

$$
M_{r C}=2 k_{\lambda r} \cdot \lambda_{r} \cdot \frac{A_{r}^{2}}{4}=\frac{1}{2} k_{\lambda r} \cdot \lambda_{r} \cdot A_{r}^{2}
$$

Dla przypadku pośredniego przyłożenia momentu $\mathrm{M}_{\mathrm{rC}}$ do czołownic (poprzez ślizgi sprężyste) zachodzi następujący bilans przemieszczeń kątowych:

$$
\lambda_{r}+\xi_{r S}=\frac{M_{r C}}{2 K_{r Z A S T}^{o}}
$$

Na podstawie wzorów (20), (24) i (26) otrzymuje się wyróżnik , $9 ”$ proporcji sztywnościowych w obrębie poziomów ramowych ,,r”:

$$
\vartheta=\frac{\xi_{r S}}{\lambda_{r}+\xi_{r S}}=\frac{K_{r Z A S T}^{o}}{K_{r}^{o}}=\frac{1}{1+4 \frac{K_{r}^{o}}{k_{\lambda r} \cdot A_{r}^{2}}}
$$

Wartość liczbowa wyróżnika $\vartheta$ powinna być jednakowa na wszystkich wyższych, racjonalnie zaprojektowanych, poziomach ramowych $(\vartheta<<1)$.

$$
\lim _{K_{r}^{o} \rightarrow \infty} \vartheta ; \quad \lim _{k_{\lambda r} \rightarrow 0} \vartheta
$$

Racjonalizacja konstrukcyjna pełnej struktury sprężystej wagonu (r>1) ma sens jedynie wtedy, gdy sztywności $\mathrm{K}_{\mathrm{r}}^{\mathrm{o}}$ oraz $\mathrm{k}_{\lambda_{\mathrm{r}}}$ poziomów ramowych wyższych niż pierwszy, mają wartości skończone. Kolejne poziomy ramowe przeanalizowano począwszy od pierwszego.

Do wzoru (2) należy podstawić wartości sił w przekątnie położonych sprężynach wózka, wynikające z ogólnego kąta zwichrowania ugięć usprężynowania 1 -go stopnia pojedynczej osi $\xi_{\text {SPR }}$. Siły te są opisane następująco:

$$
\begin{aligned}
& F_{1 L}+F_{1 P}+F_{2 L}+F_{2 P}=4 \bar{F} \\
& F_{1 L}+F_{2 P}=\bar{F}+\xi_{S P R} \frac{A}{2} k_{\lambda 1} \\
& F_{1 P}+F_{2 L}=\bar{F}-\xi_{S P R} \frac{A}{2} k_{\lambda 1}
\end{aligned}
$$

gdzie: A - poprzeczny rozstaw sprężyn każdego zestawu kół.
Współczynnik bezpiecznej nierównomierności nacisków przekątnych (2) wózka oznaczono jako $\delta_{\alpha} \mathrm{i}$ wynosi:

$$
\delta_{\alpha}=\frac{\left|F_{1 L}+F_{2 P}\right|-\left|F_{2 L}+F_{1 P}\right|}{F_{1 L}+F_{1 P}+F_{2 L}+F_{2 P}}
$$

Każdy z wózków 32- osiowego wagonu może znajdować się na odcinku toru o innym zwichrowaniu. Wózków jest 16. Dla i-tego wózka, na mocy (20), (29) i (30) można napisać:

$$
\delta_{\alpha i}=\frac{4 \alpha_{i} \cdot k_{\lambda 1} \cdot K_{1}^{o} \cdot A_{1}}{Q_{w} \cdot\left(4 K_{1}^{o}+A_{1}^{2} k_{\lambda 1}\right)} ; \quad(i=1,2, \ldots, 16)
$$

gdzie: $\mathrm{Q}_{\mathrm{w}}$ - nacisk jednego wózka na tor; $4 \bar{F}=Q_{w}$,

$\mathrm{K}^{\mathrm{o}}{ }_{1}$ - sztywność skrętna ramy wózka (poziom 1 ), mierzona na długości $\mathrm{B}=\mathrm{B}_{1}$,

$\mathrm{A}^{2}{ }_{1} \mathrm{k}_{\lambda 1}$ - sztywność bocznego pochylenia kompletnego usprężynowania wózka.

Współczynnik nierównomierności nacisków przekątnych kół dwuosiowego wózka, na mocy (31), można wyrazić następująco:

$$
\delta_{\alpha w}=\frac{4 \cdot \alpha_{1} \cdot k_{\lambda 1} \cdot A_{1}}{Q_{w} \cdot\left(4+\frac{A^{2} k_{\lambda 1}}{K_{1}^{o}}\right)} ; \quad \lim _{K_{1}^{0} \rightarrow \infty} \delta_{\alpha w}=\frac{\alpha_{1} \cdot k_{\lambda 1} \cdot A_{1}}{m_{w a g} \cdot g}
$$

W praktyce wymagania UIC dotyczące warunków sprzegania taboru nie pozwalają liczyć się $\mathrm{Z}$ przypadkiem $\mathrm{K}_{1}{ }^{\circ} \rightarrow \infty$, natomiast jest możliwy (i celowy) przypadek $\mathrm{K}_{1}{ }^{\mathrm{o}} \rightarrow 0$, (typu Diamond).

Wózek $\mathrm{z}$ ramą nieskończenie sztywną $\mathrm{w}$ stanie "ładowny" nie mógłby w ogóle pokonywać większych wichrowatości toru niż wynikają z ograniczników ugięć usprężynowania 1-go stopnia, zaś wózek w stanie "próżny" nie spełniałby warunku bezpiecznych nacisków przekątnych. To uzasadnia stosowanie wózków typu "Diamond" w najnowszych konstrukcjach wagonów "dziobowych".

Rozpatrzono wózek dwuosiowy, dla którego wzór opisujący współczynnik nacisków przekątnych według (2) w torze zwichrowanym ma postać (32), gdzie:

$\alpha_{1}$ - boczna przechyłka rampy pod wózkiem, $A_{1}-$ rozstaw sprężyn, s - rozstaw okręgów tocznych kół, $\mathrm{k}_{\lambda_{1}}$ - sztywność reprezentatywnej sprężyny pierwszego stopnia, $\mathrm{K}_{1}^{\mathrm{o}}$ - sztywność skrętna ramy poziomu pierwszego.

Pierwszy "poziom ramowy" niezbywalnie ma dwie sztywności „, $\mathrm{K}_{1}^{\mathrm{o}}{ }_{1}$ i „ „, $\mathrm{k}_{\lambda 1}$ ”. Wyższe (,racjonalne”) poziomy ze ślizgami sprężystymi mają także dwie sztywności, $\mathrm{K}_{\mathrm{r}}^{\mathrm{o}}$ i $\mathrm{k}_{\lambda_{\mathrm{r}}}(\mathrm{r}=2 \ldots 5)$. Zatem wszystkie poziomy ramowe potraktowano metodycznie jednakowo. Jeżeli bowiem założy się, że wszystkie te poziomy mają $\mathrm{w}$ narożach podporowych ogólnie pojmowane ślizgi sprężyste z ogranicznikami bocznych ugięć opisanymi kątowo przez $\lambda_{r}$, to również wózek traktuje się 
podobnie, przy czym usprężynowanie 1-go stopnia jest traktowane jako ,ślizgi sprężyste względem toru” z ogranicznikiem (traktowanym kątowo) bocznych ugięć w obrębie usprężynowania.

Wzięto pod rozwagę również przypadek graniczny, kiedy wózek dwuosiowy nie jest usprężynowany, czyli $\mathrm{k}_{\lambda 1}=\infty$ a wszystkie ślizgi boczne są sztywne. Dla takiego przypadku wzór (32) przybiera postać:

$$
\delta_{\alpha w}=\frac{4 \cdot \alpha_{1} \cdot K_{1}^{o} \cdot A_{1}}{Q_{w} \cdot\left(\frac{4 K_{1}^{o}}{k_{\lambda 1}}+A_{1}^{2}\right)} ; \quad \lim _{k_{\lambda 1} \rightarrow \infty} \delta_{\alpha w}=\frac{4 \cdot \alpha_{1} \cdot K_{1}^{o}}{Q_{1} \cdot A_{1}}
$$

Zatem, jeżeli każdy r-ty nieusprężynowany poziom ramowy miałby zapewnić taką samą wartość współczynnika, to $\delta_{a r}=\delta_{\alpha}=$ const, wtedy należałoby spełnić formalny warunek $\mathrm{K}_{1}^{\mathrm{o}}=\mathrm{K}^{\mathrm{o}}{ }_{1 \mathrm{ZAST}} \mathrm{i}$ powyższy wzór, dla poziomu ' 'r', przekształcić następująco:

$$
\begin{gathered}
K_{r Z A S T}^{o}=\frac{\delta_{\alpha r} \cdot Q_{r} \cdot A_{r}}{4 \cdot \alpha_{r}} ; \quad \alpha_{r}=\frac{i}{2 \cdot 10^{3} \cdot s} \cdot B_{r} \\
K_{r Z A S T}^{o}=\frac{10^{3} \cdot \delta_{\alpha r} \cdot A_{r} \cdot Q_{r} \cdot s}{2 \cdot B_{r} \cdot i} ; \quad r=(2 \ldots 5)
\end{gathered}
$$

gdzie: $\mathrm{B}_{\mathrm{r}}$ - baza $\mathrm{r}$ - tego poziomu ramowego, $\mathrm{i}-$ wzniesienie [\%o], $\mathrm{Q}_{\mathrm{r}}$ - łączny nacisk r-tego poziomu ramowego na tor, $\mathrm{K}_{\text {rZAST }}^{\mathrm{o}}-$ według (20).

Wzór (34) pozwala wyznaczyć reprezentatywną (zastępczą) sztywność skrętną wszystkich poziomów w funkcji $\delta_{\alpha r}$ w sensie (20). Na tej podstawie wyznacza się jedną $\mathrm{z}$ dwóch składowych sztywności występujących w (20). Drugą z tych sztywności traktuje się jako narzuconą.

W przypadku wózków, jako narzuconą przyjmuje się sztywność $\mathrm{k}_{\lambda 1}$, którą wyznacza się $\mathrm{z}$ warunków sprzęgania taboru UIC w warunkach "próżny - ładowny'. Zatem konstruktor wózka - jak wyżej wspomniano - musi z konieczności zrealizować odpowiednio niewielką sztywność skrętną ramy wózka $\mathrm{K}^{\mathrm{o}}$.

W przypadku ram wyższych poziomów jako narzuconą przyjmuje się sztywność $\mathrm{K}_{\mathrm{r}}^{\mathrm{o}}$ wynikającą $\mathrm{z}$ wytrzymałości ustroju nośnego $\mathrm{w}$ warunkach ekstremalnej nośności. W tym przypadku konstruktor dobiera sztywności ślizgów sprężystych $\mathrm{k}_{\lambda_{\mathrm{r}}}$ stosownie do narzuconej wartości współczynnika $\delta_{\alpha \mathrm{r}}=\delta_{\alpha 1}$.

W wózkach klasycznych górną granicę sztywności skrętnej ramy pierwszego poziomu (czyli wózka dwuosiowego) wyznacza się po przekształceniu wzoru (34) z uwzględnieniem (20) dla " $r$ "=1. Konstruktor powinien zapewnić sztywność nie większą od obliczeniowej:

$$
K_{1}^{o}=\frac{10^{3} \cdot \delta_{\alpha 1} \cdot Q_{1} \cdot A_{1}^{2} \cdot s \cdot k_{\lambda 1}}{B_{1} \cdot i \cdot A_{1} \cdot k_{\lambda 1}-4 \cdot 10^{3} \cdot \delta_{\alpha 1} \cdot Q_{1} \cdot s}
$$

gdzie: ' 'i, 'jest wyrażone w promilach [\%o], $\mathrm{Q}_{1}$ - nacisk jednego wózka na tor.

Wyżej został przeanalizowany poziom pierwszy, zatem od tej chwili sztywność $\mathrm{K}_{1 \mathrm{R}}^{\mathrm{o}}\left(\delta_{\alpha}, \mathrm{k}_{\lambda 1}\right)$ traktuje się jako znaną, zapewniająca odpowiednio bezpieczne naciski w torze zwichrowanym na mocy (35).

Wyjściowa wartość $k_{\lambda_{1}}$ musi być wyznaczona $z$ eksploatacyjnego warunku sprzęgania pojazdów szynowych UIC $w$ ramach dopuszczalnego przyrostu ugięć $\Delta_{\text {SPRZ }}$ W warunkach "próżny-ładowny" w zakresie $\Delta_{\mathrm{R}}$ stanu kół "nowe-zużyte".

Jako $\zeta$ oznaczono ugięcia usprężynowania, jako Q oznaczono nacisk wagonu "próżnego" / "ładownego" na tor odpowiednio według oznaczeń "PROZ " / "LAD".

$$
\begin{aligned}
& \zeta_{P R O Z}=\frac{Q_{P R O Z}}{64 k_{\lambda 1}} ; \quad \zeta_{L A D}=\frac{Q_{L A D}}{64 k_{\lambda 1}} \\
& \zeta_{L A D}-\zeta_{P R O Z}=\Delta_{S P R Z}-\Delta_{R}
\end{aligned}
$$

gdzie: $\Delta_{\mathrm{R}}-$ dopuszczalne zużycie promieni tocznych kół w eksploatacji,

$\Delta_{\text {SPRZ }}-$ dopuszczalna niewspółosiowość zderzaków w obrębie zarządu kolejowego.

Zatem:

$$
64 k_{\lambda 1} \cdot\left(\Delta_{S P R Z}-\Delta_{R}\right)=Q_{L A D}-Q_{P R O Z}
$$

i stąd

$$
k_{\lambda 1}=\frac{Q_{L A D}-Q_{P R O Z}}{64\left(\Delta_{S P R Z}-\Delta_{R}\right)}
$$

Na mocy wzorów (36) i (37), można według (20), wyznaczyć $\mathrm{k}_{\lambda 1}$ a następnie $\mathrm{K}^{\mathrm{o}}{ }_{1 \text { ZAST }}$ według (38):

$$
K_{1 Z A S T}^{o}=\frac{K_{1}^{o} \cdot k_{\lambda 1} \cdot A_{1}^{2}}{2 k_{\lambda 1} \cdot A_{1}^{2}+8 K_{1}^{o}}
$$

Mając jednoznacznie określoną wartość liczbową $\vartheta$ według (27), można końcowe rozwiązanie bilansu analizowanych pochyleń kolejno $\mathrm{w}$ dwóch stanach, "próżny" - "ładowny", wyrazić następująco:

$$
\begin{aligned}
& \lambda_{r}+\xi_{1 S}=\alpha_{1 \max } \\
& \xi_{1 S}=\alpha_{1 \max } \cdot \vartheta \\
& \lambda_{1}=\alpha_{1 \max }-\xi_{1 S}
\end{aligned}
$$

Wózki biegowe określają stopień bezpieczeństwa dla całego, racjonalnie zaprojektowanego, specjalnego pojazdu wielopoziomowego. Spełnienie warunku (35), stosownie do narzuconej wartości $\delta_{\alpha 1}$ według (32) stanowi najpoważniejsze wyzwanie wobec konstruktora całego pojazdu.

Ze względu na wymagania UIC bardzo trudno jest zaprojektować wózek klasyczny, z ramą skrzynkowa, zapewniający wysoki stopień bezpieczeństwa na przekątne naciski w torze wichrowatym. Albowiem w tym celu rama wózka musi mieć małą sztywność skrętną. 
Zatem należy postulować, aby konstrukcja wózków dla wagonów wielopoziomowych była raczej zbliżona do wzoru towarowego wózka DIAMOND, zaprojektowanego specjalnie dla złych stanów toru. Praktyka pokazała, że większość wagonów "dziobowych" ma ramy skrzynkowe, co ogranicza ich eksploatacyjne zastosowanie.

\section{Struktura sprężysta wyższych poziomów ramo- wych}

Wyższe poziomy ramowe muszą $\mathrm{w}$ stosunku do poziomu pierwszego spełniać warunki (32) i (39) podobnego stopnia bezpieczeństwa na naciski według zasady $\delta_{\alpha 1}=\delta_{\alpha r},(r=2,3,4,5)$ zgodnie z (34) w stanach "próżny" - 'ładowny", czyli:

$$
\frac{K_{r Z A S T}^{o}}{Q_{r}}=\frac{10^{3} \cdot \delta_{\alpha r} \cdot A_{r} \cdot s}{2 \cdot B_{r} \cdot i_{\max }}
$$

gdzie $\mathrm{Q}_{\mathrm{r}}$ - nacisk sumaryczny kół pod $\mathrm{r}$ - tym poziomem ramowym.

Zatem

$$
\frac{K_{r Z A S T}^{o}}{K_{(r+1) Z A S T}^{o}}=\frac{Q_{r} \cdot A_{r} \cdot B_{r+1}}{Q_{r+1} \cdot B_{r} \cdot A_{r+1}}
$$

oraz

$$
\frac{K_{r Z A S T}^{o}}{K_{(r-m) Z A S T}^{o}}=\frac{2^{r-m} A_{r} \cdot B_{r-m}}{B_{r} \cdot A_{r-m}}
$$

gdyż

$$
Q_{r-m}=2^{r-m} Q_{r}
$$

Przyjmując zasadę „równych szans” nierównomierności $\delta_{\alpha}$ nacisków przekątnych przy wchodzeniu kolejnych ram wagonu w obręb zwichrowania toru, na mocy (38), przy poszanowaniu (40) do (43), wyznacza się sztywności na międzyramowych ślizgach sprężystych wszystkich wyższych poziomów:

$$
k_{\lambda r}=\frac{1}{A_{r}^{2}} \cdot \frac{8 K_{r}^{o} \cdot K_{r Z A S T}^{o}}{K_{r}^{o}-2 K_{r Z A S T}^{o}}
$$

Pozostały do wyznaczenia wartości kątowych luzów sprężystych $\lambda_{\text {r }}$.

Na mocy (22) można napisać:

$$
\begin{aligned}
& \alpha_{1 \max }=\xi_{1 S}+\lambda_{1} \\
& \alpha_{2 \max }=\left(\xi_{1 S}+\lambda_{1}\right)+\left(\xi_{2 S}+\lambda_{2}\right)
\end{aligned}
$$

Zatem w wyniku odpowiednich przekształceń otrzymuje się:

$$
\begin{aligned}
& \left(\xi_{2 S}+\lambda_{2}\right)=\alpha_{2 \max }-\alpha_{1 \max } \\
& \left(\xi_{3 S}+\lambda_{3}\right)=\alpha_{3 \max }-\alpha_{2 \max }-\alpha_{1 \max } \\
& \left(\xi_{4 S}+\lambda_{4}\right)=\alpha_{4 \max }-\alpha_{3 \max }-\alpha_{2 \max }-\alpha_{1 \max } \\
& \left(\xi_{5 S}+\lambda_{5}\right)=\alpha_{5 \max }-\alpha_{4 \max }-\alpha_{3 \max }-\alpha_{2 \max }-\alpha_{1 \max }
\end{aligned}
$$

albo w postaci zwartej:

$$
\left(\xi_{r S}+\lambda_{r}\right)=\alpha_{r \max }-\sum_{i=1}^{r} \alpha_{i \max }
$$

Uwzględniając (34), oraz wyrażając " 'i" w [\%o], otrzyma się:

$$
\left(\xi_{r S}+\lambda_{r}\right)=\frac{i_{\max }}{2 \cdot 10^{3} s}\left(B_{r}-\sum_{i=1}^{r-1} B_{i}\right), \quad(r=1,2, \ldots n)
$$

Na podstawie (27) wiadomo, że:

$$
\vartheta=\frac{\xi_{r S}}{\lambda_{r}+\xi_{r S}}
$$

Zatem

$$
\xi_{r S}=\frac{\vartheta \cdot i_{\max }}{2 \cdot 10^{3} S}\left(B_{r}-\sum_{i=1}^{r-1} B_{i}\right), \quad(r=1,2, \ldots n)
$$

W tym miejscu należy zauważyć, że według (27) $\vartheta$ $<<1$.

Dla każdego poziomu ramowego można więc napisać:

$$
\lambda_{r}=\frac{(1-\vartheta) \cdot i_{\max }}{2 \cdot 10^{3} s}\left(B_{r}-\sum_{i=1}^{r-1} B_{i}\right), \quad(r=1,2, \ldots n)
$$

Wzory (44) $\div$ (51) pozwalają na wykonanie szczegółowych obliczeń wartości sztywności $\mathrm{k}_{\lambda_{\mathrm{r}}}$ i koniecznych luzów $\lambda_{\mathrm{r}}$ na ogranicznikach ugięć sprężystych ślizgów międzyramowych.

Dopiero $\mathrm{w}$ tym miejscu zaistniały pełne warunki dla szczegółowego badania stateczności struktury wagonu wielopoziomowego.

Znając wszystkie sztywności $\mathrm{K}_{\mathrm{r}}^{\mathrm{o}}$ ram układu, znając wartości kątów pochylenia ram $\xi_{\mathrm{r}}$ i kątów opisujących wartości graniczne luzów sprężystych $\lambda_{\mathrm{r}}$, przy znajomości parametrów geometrycznych i dynamicznych (wymiary i masy elementów obiektu) można obliczeniowo wyznaczyć przyrosty energii potencjalnej według wzoru (12) w funkcji kąta pochylenia toru $\xi_{\mathrm{t}}$ występującego w $\xi_{\mathrm{i}}$ według (4) i (6). Kąty pochylenia poszczególnych ram, występujące we wzorze (8) są określone wzorami (52):

$$
\xi_{k}=\xi_{t}+\sum_{i=1}^{i=k}\left(\xi_{i S}+\lambda_{i}\right) ; \quad(i=1,2, . . k, .5)
$$

Poszczególne momenty reakcyjne na czołownicach $\mathrm{M}_{\mathrm{rC}}$ wyznacza się według wzorów (57) i (58). Momenty te określają kąty skrętnych odkształceń sprężystych $\xi_{\text {rs }} \quad$ W układzie i kąty położeń poszczególnych ram $\xi_{\mathrm{r}}$ względem grawitacyjnego układu odniesienia.

Katy $\xi_{\mathrm{r}}$ opisane przez (54) zostały wyznaczone przy założeniu konstrukcji ślizgów sztywnych $\mathrm{z}$ luzami $\lambda_{\mathrm{r}}$ swobodnymi. Przy badaniu stateczności dynamicznej układu według rysunku 7 należy uwzględnić także sztywności $\mathrm{k}_{\lambda_{\mathrm{r}}}$ według (44). 
Przy bocznych pochyleniach wózka ',w' można napisać:

$$
\lambda_{w}=\frac{M_{w C}}{A_{w} k_{\lambda w}}=\frac{M_{1 C}}{A_{1} k_{\lambda 1}}
$$

Odpowiednia struktura wzorów (52) opisujących kąty pochyleń $\xi_{\mathrm{i}}\left(\xi_{\mathrm{t}}, \mathrm{k}_{\lambda \mathrm{i}}, \mathrm{K}_{\mathrm{i}}^{\mathrm{o}}\right)$ elementów układu z luzami sprężystymi według rysunku 7 , przybiera następującą postać:

$$
\begin{aligned}
& \xi_{1}=\xi_{t}+\xi_{1 S}+\lambda_{1} \\
& \xi_{2}=\xi_{t}+\xi_{1 S}+\xi_{2 S}+\lambda_{1}+\lambda_{2}
\end{aligned}
$$

Albo w postaci rozwiniętej:

$$
\begin{aligned}
& \xi_{1}=\xi_{t}+\frac{M_{1 C}}{2}\left(\frac{1}{K_{1}^{o}}+\frac{4}{A_{1}^{2} k_{1}}\right) \\
& \xi_{2}=\xi_{t}+\frac{M_{1 C}}{2}\left(\frac{1}{K_{1}^{o}}+\frac{4}{A_{1}^{2} \cdot k_{\lambda 1}}\right)+\frac{M_{2 C}}{2}\left(\frac{1}{K_{2}^{o}}+\frac{4}{A_{2}^{2} \cdot k_{\lambda 2}}\right)
\end{aligned}
$$

W postaci zwartej otrzymuje się zapis ogólny:

$$
\xi_{r}=\xi_{t}+\frac{1}{2} \sum_{i=1}^{r} M_{i C}\left(\frac{1}{K_{i}^{o}}+\frac{4}{A_{i}^{2} k_{\lambda_{i}}}\right) ; \quad(r=1,2, \ldots n)
$$

Momenty $\mathrm{M}_{\mathrm{rC}}$ wyznacza się na mocy następujących zależności:

$$
\left|\begin{array}{ccccc}
A_{11} & A_{12} & 0 & 0 & 0 \\
A_{21} & A_{22} & A_{23} & 0 & 0 \\
A_{31} & A_{32} & A_{33} & A_{34} & 0 \\
A_{41} & A_{42} & A_{43} & A_{44} & A_{45} \\
A_{51} & A_{52} & A_{53} & A_{54} & A_{55}
\end{array}\right| \begin{array}{|l}
M_{1 C} \\
M_{2 C} \\
M_{3 C} \\
M_{4 C} \\
M_{5 C}
\end{array}|=| \begin{gathered}
C_{1} \\
C_{2} \\
C_{3} \\
C_{4} \\
C_{5}
\end{gathered} \mid
$$

gdzie oznaczono:

$A_{11}=2+\frac{m_{1} \cdot g \cdot h_{1}}{2 K_{1}^{o}} ; \quad A_{12}=-1 ; \quad C_{1}=m_{1} \cdot g \cdot h_{1} \cdot\left(\xi_{t}+\lambda_{1}\right)$ $A_{21}=\frac{m_{2} \cdot g \cdot h_{2}}{2 K_{1}^{o}} ; \quad A_{22}=2+\frac{m_{2} \cdot g \cdot h_{2}}{2 K_{2}^{o}} ; \quad A_{23}=-1 ;$

$C_{2}=m_{2} \cdot g \cdot h_{2} \cdot\left(\xi_{t}+\lambda_{1}+\lambda_{2}\right)$,

$A_{31}=\frac{m_{3} \cdot g \cdot h_{3}}{2 K_{1}^{o}} ; \quad A_{32}=\frac{m_{3} \cdot g \cdot h_{3}}{2 K_{2}^{o}} ; \quad A_{33}=2+\frac{m_{3} \cdot g \cdot h_{3}}{2 K_{3}^{o}} ;$

$A_{34}-1 ; \quad C_{3}=m_{3} \cdot g \cdot h_{3} \cdot\left(\xi_{t}+\lambda_{1}+\lambda_{2}+\lambda_{3}\right)$

$A_{41}=\frac{m_{4} \cdot g \cdot h_{4}}{2 K_{1}^{o}} ; \quad A_{42}=\frac{m_{4} \cdot g \cdot h_{4}}{2 K_{2}^{o}} ; \quad A_{43}=\frac{m_{4} \cdot g \cdot h_{4}}{2 K_{3}^{o}} ;$

$A_{44}=2+\frac{m_{4} \cdot g \cdot h_{4}}{2 K_{4}^{o}} ; \quad A_{45}=-1 ;$

$C_{4}=m_{4} \cdot g \cdot h_{4} \cdot\left(\xi_{t}+\lambda_{1}+\lambda_{2}+\lambda_{3}+\lambda_{4}\right) ;$
$A_{51}=\frac{m_{5} \cdot g \cdot h_{5}}{2 K_{1}^{o}} ; \quad A_{52}=\frac{m_{5} \cdot g \cdot h_{5}}{2 K_{2}^{o}} ; \quad A_{53}=\frac{m_{5} \cdot g \cdot h_{5}}{2 K_{3}^{o}} ;$

$A_{54}=\frac{m_{5} \cdot g \cdot h_{5}}{2 K_{4}^{o}} ; \quad A_{55}=2+\frac{m_{5} \cdot g \cdot h_{5}}{2 K_{5}^{o}} ;$

$C_{5}=m_{5} \cdot g \cdot h_{5} \cdot\left(\xi_{t}+\lambda_{1}+\lambda_{2}+\lambda_{3}+\lambda_{4}+\lambda_{5}\right)+m_{5} \cdot g \cdot \Delta_{5}-\frac{V^{2}}{R} m_{5} \cdot h_{5} ;$

Po wyznaczeniu wartości momentów "na czołownicach" $\mathrm{M}_{\mathrm{rC}}$ (według rys. 6) - na mocy wzorów (57) i (58) z uwzględnieniem kątów $\xi_{\mathrm{i}}$ według (52), badanie stateczności struktury sprężystej wagonu według warunków (4) $\div$ (11) stanowi już tylko zadanie rachunkowe.

Struktura wzorów $(52) \div(58)$ w obliczeniach przykładowych, na mocy wzoru (12) może zostać znacznie uproszczona albowiem w praktyce kolejowej $\Theta_{5}<<0,1$. Kąty pochylenia niższych ram mają wartości mniejsze, niż kąt pochylenia ramy najwyższej (rysunek 7).

Do obliczeń przyjęto (z nadmiarem) wartość najwyższą $\Theta_{5} \approx 0,1$.

Przyjęto kolejno: $\lambda_{\mathrm{j}}=\varepsilon_{\mathrm{j}} \cdot \xi_{\mathrm{t}}, \xi_{\mathrm{js}}=\rho_{\mathrm{j}} \cdot \xi_{\mathrm{t}}$; przy czym:

$$
\begin{aligned}
& \lambda_{j}=\varepsilon_{j} \cdot \xi_{t} ; 1>>\varepsilon_{j} \geq 0 \\
& \xi_{j S}=\rho_{j} \cdot \xi_{t} ; \quad 1>>\rho_{j} \geq 0
\end{aligned} \quad \text { oraz: } \Theta_{i}=\sum_{j=1}^{j=i}\left(\rho_{j}+\varepsilon_{j}\right)
$$

Przyjmując $\rho_{\mathrm{j}} \approx \varepsilon_{\mathrm{j}}$ oraz $\rho_{\mathrm{j}} \approx \rho=$ const, otrzyma się:

$$
\begin{aligned}
& \Theta_{i} \approx 2 \sum_{j=1}^{j=i} \rho_{j} ; \quad \Theta_{5} \approx 2 \sum_{j=1}^{j=5} \rho_{j}= \\
& =2\left(\rho_{1}+\rho_{2}+\rho_{3}+\rho_{4}+\rho_{5}\right)=10 \rho
\end{aligned}
$$

Jeśli $\Theta_{5} \approx 0,1$, to $\rho \approx 0,01$, czyli $\rho_{\mathrm{j}} \approx \varepsilon_{\mathrm{j}} \approx 0,01$.

Wtedy

$\left|\Delta U_{W Y S}\right|=\frac{g}{2} \sum_{r=0}^{n-1} \sum_{i=1}^{n-r} m_{i+r} \cdot\left(\sum_{i=1}^{i+r} H_{i}-h_{i+r}\right) \cdot \theta_{i}^{2} \cdot \xi_{t}^{2}+m_{5} \cdot g \cdot \Delta_{5} \cdot \xi_{t} \cdot \theta_{5}$

albo : $\left|\Delta U_{W Y S}\right|=[A] \cdot \xi_{t}^{2}+C \cdot \Delta_{5} \cdot \xi_{t}$

gdzie : $C=m_{5} \cdot g \cdot \theta_{5} ; \quad[A]=\frac{g}{2} \sum_{r=0}^{n-1} \sum_{i=1}^{n-r} m_{i+r} \cdot\left(\sum_{i=1}^{i+r} H_{i}-h_{i+r}\right) \cdot \theta_{i}^{2}$

Stąd

$\Delta U_{S P R}\left(\xi_{t}\right)=\sum_{i=1}^{n} \frac{L_{o W A G}}{2^{i}}\left(2 \cdot K_{i}^{o} \cdot \xi_{i S}^{2}+K_{\lambda i}^{o} \cdot \lambda_{i}^{2}\right)$

$\lambda_{i}=\varepsilon_{i} \cdot \xi_{t} ; \quad \xi_{i S}=\rho_{i} \cdot \xi_{t} ; \quad$ zatem $: \Delta U_{S P R}\left(\xi_{t}\right)=[B] \cdot \xi_{t}^{2}$

przyczym: $[B]=\sum_{i=1}^{n} \frac{L_{o W A G}}{2^{i}}\left(2 \cdot K_{i}^{o} \cdot \rho_{i}^{2}+K_{\lambda_{i}}^{o} \cdot \varepsilon_{i}^{2}\right)$

\section{Przyklad obliczeniowy}

W przykładzie zostało wykazane, że wagon ładowny 32-osiowy zaprojektowany do przejazdu przez rampę promową $(\mathrm{i}=25 \%$ ), przy założeniu, że posiada tylko luz na ślizgu bocznym $\lambda_{1}$ (rys 7) i wózki o ramie 
skrzynkowej oraz porusza się $\mathrm{w}$ torze prostym $\mathrm{z}$ bardzo małą prędkością $\mathrm{V}<<5 \mathrm{~m} / \mathrm{s}$, nie spełnia stateczności strukturalnej $\mathrm{w}$ zakresie przechyłek toru stosowanych na liniach PKP. Badaniu został poddany również wagon zaprojektowany według wichrowatości rampy zwykłej $(i=6 \%$ ) przy takich samych założeniach. Obliczenia zostały wykonane na podstawie wzorów przedstawionych w opracowaniu.

\subsection{Założenia do obliczeń}

Masy:

$\mathrm{m}_{\text {wag }}=672 \cdot 10^{3} \mathrm{~kg}$, masa wagonu ładownego (brutto) [3],

$\mathrm{m}_{\text {proz }}=272 \cdot 10^{3} \mathrm{~kg}$, masa wagonu próżnego [3],

$\mathrm{m}_{\text {lad }}=400 \cdot 10^{3} \mathrm{~kg}$, masa ładunku [3],

masy ram: $m_{1}=5500 \mathrm{~kg}, m_{2}=7000 \mathrm{~kg}, \mathrm{~m}_{3}=$ $14000 \mathrm{~kg}, \mathrm{~m}_{4}=18000 \mathrm{~kg}$,

$\mathrm{m}_{5}=\mathrm{m}_{\text {lad }}+\mathrm{m}_{\text {5ramy }}=436 \cdot 10^{3} \mathrm{~kg}$,

gdzie: $m_{\text {5ramy }}=36000 \mathrm{~kg}$, masa ramy poziomu piątego, $\mathrm{m}_{5}$, masa poziomu piątego wraz $\mathrm{z}$ ładunkiem.

Wymiary baz podłużnych poziomów ramowych:

$\mathrm{B}_{1}=1500 \mathrm{~mm}, \mathrm{~B}_{2}=2000 \mathrm{~mm}, \mathrm{~B}_{3}=6000$ $\mathrm{mm}, \mathrm{B}_{4}=12000 \mathrm{~mm}$,

$\mathrm{B}_{5}=43120 \mathrm{~mm}$, długość ramy poziomu $5 \mathrm{z}$ ładunkiem,

Rozstaw ślizgów bocznych dla poszczególnych poziomów:

$A_{1}=2036 \mathrm{~mm}, A_{n}=2000 \mathrm{~mm}(\mathrm{n}=2 . .5)$,

$>$ Położenie środka masy poszczególnych poziomów ramowych wg rys 7 :

$\mathrm{H}_{\mathrm{n}}=0,8 \mathrm{~m}(\mathrm{n}=1 . .5), \mathrm{h}_{\mathrm{n}}=0,2 \mathrm{~m}(\mathrm{n}=1 . .5)$,

$>$ Kątowe luzy sprężyste:

$\lambda_{1} \neq 0, \lambda_{n}=0(\mathrm{n}=2 . .5)$

$>$ Współczynnik zagrożenia bezpieczeństwa ze względu na minimalne naciski koła na szynę $\delta_{\alpha}=0,3$,

$>$ Współczynniki konstrukcyjne: $\Theta_{5} \approx 0,1$, to $\rho \approx$ 0,01 , czyli $\rho_{\mathrm{j}} \approx \varepsilon_{\mathrm{j}} \approx 0,01$,

Wzniesienie ekstremalne jednego toku szynowego $\mathrm{i}=25 \%$, (w obrębie rampy promowej),

$\mathrm{V}<<5 \mathrm{~m} / \mathrm{s}, \mathrm{R}=\infty \mathrm{m}, \xi_{\mathrm{t}}>0 \mathrm{deg}$.

\subsection{Kolejność obliczeń}

1. Wyznaczenie sztywności sprężyn I stopnia $z$ warunku sprzęgania.

Z [1] - str. 29, odczytano wartości granicznych położeń zderzaków względem główki szyny dla wagonów towarowych;

$$
h_{\max }=1065 \mathrm{~mm}, \quad h_{\min }=940 \mathrm{~mm}
$$

Biorąc pod uwage graniczne promieniowe zużycie okręgu tocznego $\Delta_{R}=35 \mathrm{~mm}$ otrzyma się różnicę ugięć $\Delta_{\text {SPRZ }}$ usprężynowania pomiędzy stanami "próżny" - "ładowny" o wartości $90 \mathrm{~mm}$.

Przy założeniu:

$$
\begin{aligned}
& Q_{L A D}=m_{\text {wag }} \cdot g=6,59 \cdot 10^{6} \mathrm{~N} \\
& Q_{P R O Z}=m_{\text {proz }} \cdot g=2,667 \cdot 10^{6} \mathrm{~N}
\end{aligned}
$$

oblicza się sztywność jednej sprężyny, jaka powinna być zachowana dla wagonu:

$$
k_{1}=\frac{Q_{L A D}-Q_{P R O Z}}{64\left(\Delta_{S P R Z}-\Delta_{R}\right)}=6,81 \cdot 10^{5} \frac{\mathrm{N}}{\mathrm{m}}
$$

gdzie: Q - nacisk wagonu "próżnego" / "ładownego" na tor odpowiednio według oznaczeń "PROZ " / "LAD",

2. Obliczenie pionowych sił zewnętrznych działających na poszczególne poziomy ramowe układu statycznie wyznaczalnego $\mathrm{Q}_{\mathrm{n}}$ :

$$
\begin{gathered}
Q_{\text {wlad }}=\left(m_{\text {5ramy }}+m_{\text {lad }}\right) \cdot g=4,276 \cdot 10^{6} \mathrm{~N}, \quad Q_{5}=\frac{Q_{\text {wlad }}}{2}=2,138 \cdot 10^{6} \mathrm{~N} \\
Q_{4}=\frac{Q_{5}+m_{4} g}{2} \Rightarrow Q_{4}=1,156 \cdot 10^{6} \mathrm{~N} \\
Q_{3}=\frac{Q_{4}+m_{3} g}{2} \Rightarrow Q_{3}=6,472 \cdot 10^{5} \mathrm{~N} \\
Q_{2}=\frac{Q_{3}+m_{2} g}{2} \Rightarrow Q_{2}=3,579 \cdot 10^{5} \mathrm{~N} \\
Q_{1 z}=\frac{Q_{2}+m_{1} g}{2} \quad i \quad Q_{1}=2 \cdot Q_{1 z}=4,119 \cdot 10^{5} \mathrm{~N}
\end{gathered}
$$

gdzie: $\mathrm{Q}_{1 z}$ - siła działająca na pojedynczy zestaw kół, $\mathrm{g}=9,81 \mathrm{~m} / \mathrm{s}^{2}$ przyspieszenie standardowe siły ciężkości.

Maksymalne zwichrowanie toru pod każdym poziomem ramowym zależy od maksymalnego wzniosu toku szynowego i[\%o], dla jakiego projektuje się wagon. Dla toru UIC $\mathrm{s}=1,5 \mathrm{~m}$ i rampy promowej $\mathrm{i}=25$ $\%$ otrzymuje się:

$$
\alpha_{r \max }=\frac{i_{\max } \cdot B_{r}}{2 \cdot 10^{3} \cdot s}=\frac{25}{3 \cdot 10^{3}} \cdot B_{r}
$$

Gdy długość rampy torowej $\mathrm{L}$ jest mniejsza od bazy podłużnej $B_{r}$ ramy danego poziomu, to wznios wagonu jest mniejszy od wzniosu rampy i wtedy do wzoru na ekstremalny kąt skręcenia toru pod wagonem podstawia się wartość L. Dla rampy promowej i największego wzniosu stosowanego przez PKP określa się długość rampy torowej wg szkicu: 


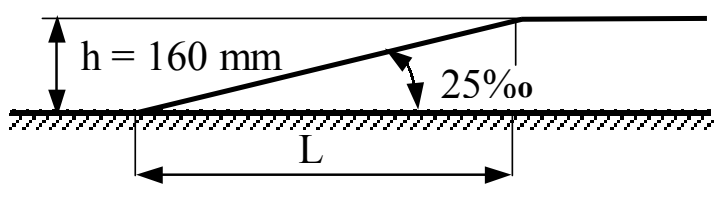

$$
h=160 \mathrm{~mm}, \quad L=\frac{10^{3} \cdot h}{i}=6,4 \mathrm{~m}
$$

Długość rampy torowej wynosi $\mathrm{L}=6,4 \mathrm{~m}$

3. Obliczenie wartości parametrów konstrukcyjnych do przejazdu przez rampę promową.

a. Poziom ramowy pierwszy (wózek kompletny):

- Wyznacza się sztywność poziomu pierwszego wg (35). Jeżeli dopuści się wartość współczynnika nierównomierności nacisków jako $\delta_{\alpha}$ $=0,3$, wtedy sztywność usprężynowania I-go stopnia może osiągać wartość

$$
k_{1}=6,81 \cdot 10^{7} \frac{\mathrm{N}}{\mathrm{m}} \quad \text { zatem }: \quad K_{1}^{o}=1,174 \cdot 10^{7} \mathrm{Nm}
$$

- Wyznacza się reprezentatywną sztywność zastępczą wg (38):

$$
K_{1 Z A S T}^{o}=5,032 \cdot 10^{6} \mathrm{Nm}
$$

- Wyróżnik wg (27): $\vartheta=0.429$

Wartość liczbowa wyróżnika $\vartheta$ powinna być jednakowa na wszystkich racjonalnie zaprojektowanych poziomach ramowych.

- Ekstremalny kąt skręcenia toru pod poziomem pierwszym: $\alpha_{1 \max }=0,716 \mathrm{deg} w g(21)$,

- Mając jednoznacznie określoną wartość liczbową $\vartheta$, można na mocy wzorów (50 i 51) wyrazić kątowe luzy i skręcenia ram:

$\lambda_{1}=0,409 \mathrm{deg}, \xi_{1 \mathrm{~s}}=0,307 \mathrm{deg}$,

b. Wyższe poziomy ramowe:

Aby wyznaczyć sztywności zastępcze poziomów II $\div \mathrm{V}$ należy oszacować skrętne sztywności konstrukcyjne tych poziomów.

Do oszacowania sztywności ram korzysta się ze wzorów Bredta [2] dla przekrojów zamkniętych, przy czym:

$\mathrm{M}_{\mathrm{s}}$ - moment skręcający,

$\mathrm{F}_{\mathrm{sr}}$ - pole powierzchni przekroju poprzecznego

pręta ograniczonego linią średnią konturu,

s - długość zamkniętej linii średniej konturu,

$\mathrm{g}_{\min }$ - najmniejsza grubość ścianki belki,

$\mathrm{G}$ - moduł sprężystości postaciowej,

$\mathrm{B}_{\mathrm{r}}$ - długość skręcanej belki

- Kąt skrętu pręta (poziomu ramowego) o długości $\mathrm{B}_{\mathrm{r}}$ wyraża się wzorem:

$$
\psi=\frac{M_{s} \cdot B_{r} \cdot s}{4 \cdot G \cdot g_{\min } \cdot F_{s r}^{2}}, \quad r=(2,3,4,5)
$$

Po odpowiednim przekształceniu powyższego wzoru otrzymuje się sztywność skrętną ramy:

$$
K_{r}^{o}=\frac{M_{s}}{\psi}=\frac{4 \cdot G \cdot g_{\min } \cdot F_{s r}^{2}}{B_{r} \cdot s}, \quad r=(2,3,4,5)
$$

- Po obliczeniu sztywności poszczególnych poziomów ramowych oblicza się sztywności zastępcze przekształcając wzór (27), biorąc pod uwagę wyróżnik $\vartheta$ obliczony dla poziomu I:

$$
K_{r Z A S T}^{o}=\vartheta \cdot K_{r}
$$

zatem:

$$
\begin{aligned}
& K_{2 Z A S T}^{o}=1,331 \cdot 10^{8} \mathrm{Nm}, \quad K_{3 Z A S T}^{o}=6,185 \cdot 10^{7} \mathrm{Nm}, \\
& K_{4 Z A S T}^{o}=7,634 \cdot 10^{7} \mathrm{Nm}, \quad K_{5 Z A S T}^{o}=1,182 \cdot 10^{8} \mathrm{Nm},
\end{aligned}
$$

- Następnie przyjmuje się wysokości poszczególnych poziomów ramowych.

Przy założeniu $\mathrm{g}_{\min }=10 \mathrm{~mm}$, wysokości poziomów ramowych wynoszą: $\mathrm{H}_{2}=500 \mathrm{~mm}$, $\mathrm{H}_{3}=600 \mathrm{~mm}, \mathrm{H}_{4}=700 \mathrm{~mm}, \mathrm{H}_{5}=750 \mathrm{~mm}, \mathrm{a}$ ich długości $\mathrm{B}_{2}<\mathrm{L}, \mathrm{B}_{3}<\mathrm{L}, \mathrm{B}_{4}=\mathrm{L}, \mathrm{B}_{5}=\mathrm{L}$.

Jeżeli baza podłużna poziomu ramowego ma wartość większą od długości rampy promowej L, to do wzoru na sztywność ramy (64) podstawia się długości rampy torowej.

- Wyznacza się sztywności na międzyramowych ślizgach sprężystych wszystkich poziomów wyższych niż pierwszy wg (44):

$$
\begin{aligned}
& k_{\lambda 1}=k_{1}, \quad k_{\lambda 2}=1,869 \cdot 10^{9} \frac{\mathrm{N}}{\mathrm{m}}, \quad k_{\lambda 3}=8,675 \cdot 10^{8} \frac{\mathrm{N}}{\mathrm{m}}, \\
& k_{\lambda 4}=1,071 \cdot 10^{9} \frac{\mathrm{N}}{\mathrm{m}}, \quad k_{\lambda 5}=1,658 \cdot 10^{9} \frac{\mathrm{N}}{\mathrm{m}}
\end{aligned}
$$

- Wartości luzów kątowych na ogranicznikach $\lambda_{n}$ oraz ekstremalny kąt zwichrowania $\alpha_{\text {rmax }}$ toru pod bazą $B_{r}$ wyznacza się na podstawie (40).

\section{Uwaga:}

Gdy długość rampy torowej $\mathrm{L}$ jest mniejsza od bazy podłużnej ramy $B_{r}$, to do wzoru na ekstremalny kat skręcenia toru wg (21) podstawia się wartość $\mathrm{L}$, w miejsce $\mathrm{B}_{\mathrm{r}}$.

$$
\begin{aligned}
& \lambda_{2}=0.136 \mathrm{deg}, \quad \lambda_{3}=0.682 \mathrm{deg}, \quad \lambda_{4}=0.682 \mathrm{deg}, \\
& \lambda_{5}=5,897 \mathrm{deg}, \alpha_{2 \max }=0,955 \mathrm{deg}, \quad \alpha_{3 \max }=2,865 \mathrm{deg}, \\
& \alpha_{4 \max }=3,056 \mathrm{deg}, \quad \alpha_{5 \max }=3,056 \mathrm{deg} .
\end{aligned}
$$

Analizując przypadek postoju wagonu na pochyleniu $\xi_{\mathrm{t}}$ traktuje się to pochylenie jako parametr.

Powyższy tok obliczeń wykonano dla rożnych wartości przechyłki toru $\xi_{\mathrm{t}}=0,0.5, \ldots 6,5 \mathrm{deg}$, oraz poprzecznego przemieszczenia ładunku $\Delta_{5}=0, \pm 50, . . \pm 500 \mathrm{~mm}$, prędkości $\mathrm{V}<<\mathrm{m} / \mathrm{s}, \mathrm{R}=\infty \mathrm{m}$, na podstawie wzorów $(59 \div 62)$. 
Bilanse energii sprężystości i wysokości posłużyły do sporządzenia wykresu ukazującego obszar stateczności (rys10) oraz granicę stateczności strukturalnej wagonu (rys 11).
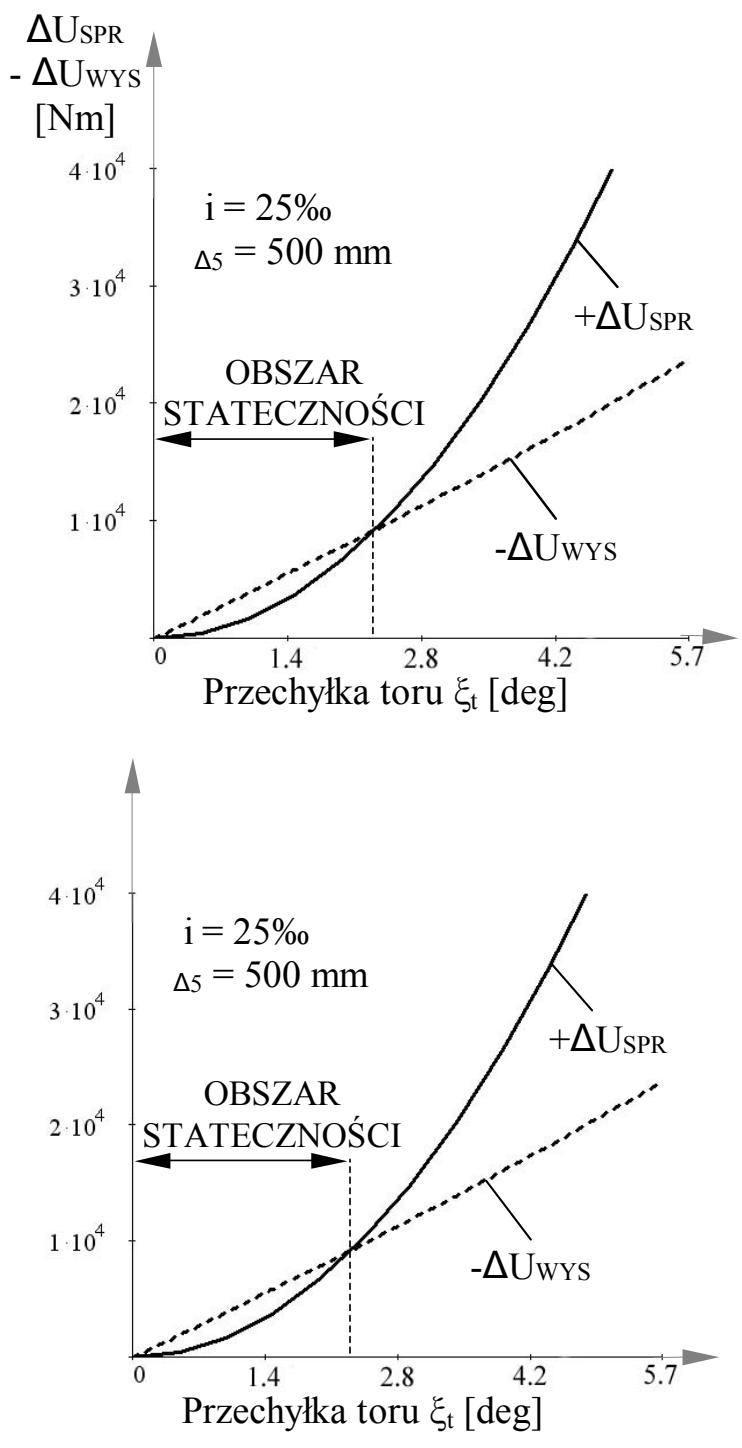

Rys. 10. Przyrosty energii sprężystości i wysokości przy przemieszczaniu poprzecznym $\Delta_{5}$ ładunku

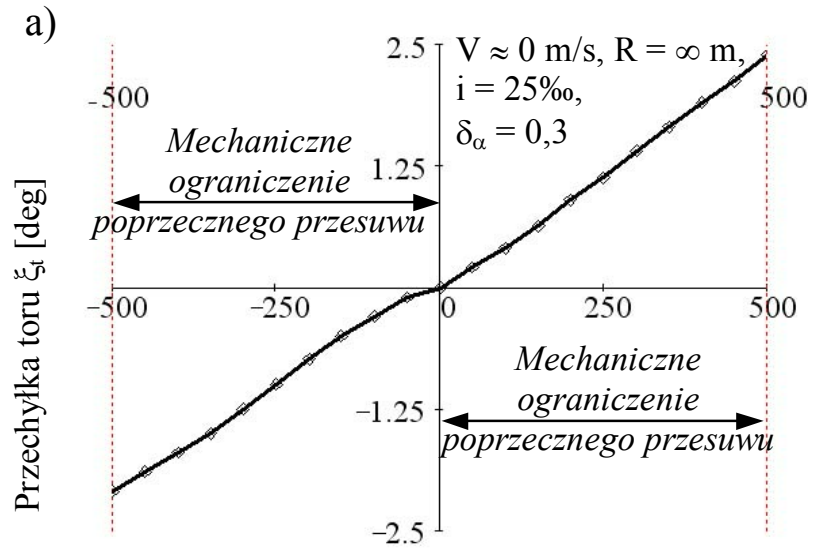

Przemieszczenie poprzeczne ładunku $\Delta_{5}[\mathrm{~mm}]$

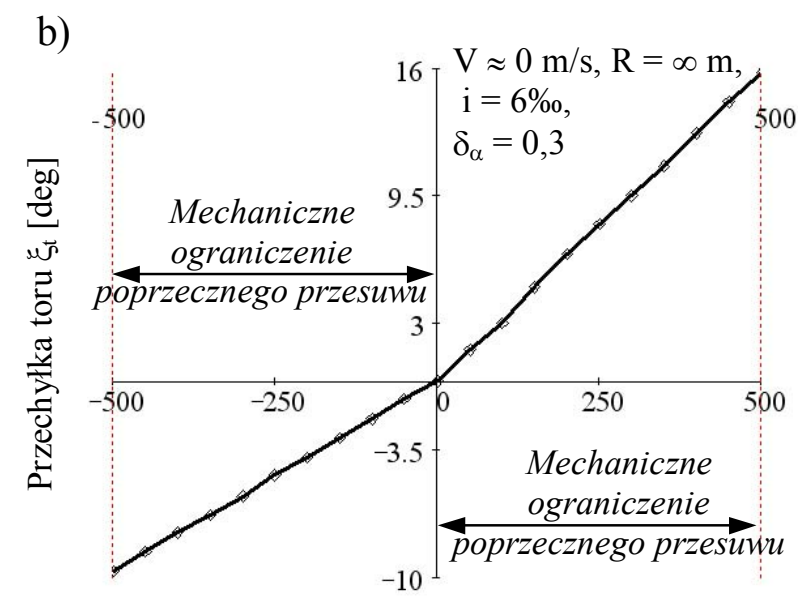

Przemieszczenie poprzeczne ładunku

$$
\Delta_{5}[\mathrm{~mm}]
$$

Rys. 11. Obszar stateczności strukturalnej wagonu zaprojektowanego do przejazdu a) przez rampe promową $\mathrm{i}=25$ $\%$ i b) przez rampe zwykłą $i=6 \%$ przy ruchu w torze prostym o różnej przechyłce

\section{Interpretacja analiz i wyników obliczeń}

Analizując stateczność wagonu należy stwierdzić, że wagon ładowny z klasycznymi wózkami skrzynkowymi, zaprojektowany dla pokonywania ekstremalnych zwichrowań toru (rampa promowa, $\mathrm{i}=25 \%$ - rys. 11a) nie zapewnia warunków bezpieczeństwa ruchu $w$ torze prostym, ponieważ obszar stateczności jego pełnej struktury sprężystej zawiera się w bardzo małym zakresie bocznej przechyłki toru.

W analogiczny sposób zostały przeprowadzone obliczenia dla wagonu ładownego, który został zaprojektowany do przejazdów przez normatywną rampę torowa, w obrębie której zwichrowanie toru wynosi i = $6 \%$. Następnie wagon ten został również poddany badaniu stateczności (w sposób analityczny) przez jego boczne pochylanie. $Z$ analizy wykresu (rys. 11b) wynika, że wagon tak zaprojektowany może poruszać się na szlakach torowych o pochyleniu toru większym niż wagon zaprojektowany do przejazdu przez rampe promowa.

Jak wykazały wstępne obliczenia dla wagonu $\mathrm{z}$ wózkami klasycznymi (rama skrzynkowa), zaprojektowanego dla ruchu $\mathrm{w}$ torze zwichrowanym, wagon taki nie nadaje się do ruchu na szlaku z normatywnymi pochyleniami bocznymi, gdyż sztywności poszczególnych poziomów ramowych są zbyt małe. Zatem dalsze analizy wagonu zostaną przeprowadzone przy zastosowaniu wózków typu Diamond.

\section{Wnioski końcowe}

1. Wymagania techniczne odnośnie do współczynników zagrożenia bezpieczeństwa na naciski przekątne $\delta_{\alpha}$ i naciski boczne $\delta_{\xi}$, są sprzeczne. 
2. Próba usunięcia tej sprzeczności przez zastosowanie ślizgów sprężystych z odpowiednio dużymi luzami na ogranicznikach (dla pokonywania znacznych wichrowatości toru) nie dała zadowalających rezultatów.

3. Dziobowy wagon wielopoziomowy $\mathrm{z}$ wózkami klasycznymi (o ramach „skrzynkowych”), zaprojektowany dla pokonywania znacznych zwichrowań toru, w torze niezwichrowanym nie zachowuje należytej stateczności strukturalnej. Jego usprężynowanie ma zbyt niskie sztywności. Wagon dziobowy z wózkami klasycznymi, zaprojektowany dla ruchu $\mathrm{w}$ torze silnie zwichrowanym, nie zapewnia bezpiecznego ruchu w torze prostym o normatywnych pochyleniach bocznych. Ten wniosek dyskwalifikuje (najszerzej stosowane $\mathrm{w}$ takich wagonach) wózki klasyczne. Oznacza to, że istniejące wagony dziobowe $\mathrm{z}$ wózkami klasycznymi nie mogą bezpiecznie pokonywać odcinków toru o znacznych zwichrowaniach.

4. Wagony dziobowe $\mathrm{z}$ wózkami klasycznymi nie mogą spełnić kryteriów bezpiecznego ruchu w torze zwichrowanym ze względu na zbyt duże nierównomierności nacisków przekątnych kół na szyny w takich warunkach.
5. Korekcyjne poprzeczne przemieszczanie ładunku wywiera technicznie istotny wpływ na warunki stateczności strukturalnej wagonu. Przemieszczanie takie stosuje się zarówno ze względu na czynniki skrajniowe, jak i na stateczność.

6. Wagon dziobowy zaprojektowany dla pokonywania znacznych zwichrowań toru najkorzystniej powinien mieć wózki z podłużnicami wahliwymi (typu "Diamond"). Temu zagadnieniu zostanie poświęcone oddzielne opracowanie szczegółowe.

\section{Literatura}

[1] Roman Marczewski, Zygmunt Płończak, Jan Podemski: ,Wagony towarowe - poradnik techniczny". Wydanie II uzupetnione. WKE Warszawa 1978.

[2] Michat E. Niezgodziński, Tadeusz Niezgodziński: ,Wzory, wykresy i tablice wytrzymałościowe" .Wydanie VI zmienione. WNT Warszawa 1996.

[3] „Instrukcja techniczno - ruchowa obstugi $i$ eksploatacji wagonów Norca 32 i Norca 24 PKP”. 